\title{
Age-specific Migration in Regional Centres and Peripheral Areas of Russia*
}

\author{
Liliya Karachurina, Nikita Mkrtchyan
}

\begin{abstract}
Ravenstein, writing in $19^{\text {th }}$ century papers, observed that migration varied with the life course. However, he did not investigate this variation in detail, as the necessary data were not then available. Age-specific migration has been a focus for researchers of migration in the $20^{\text {th }}$ and $21^{\text {st }}$ centuries. Building on this research, the current paper explores age-specific migration in Russia focussing on its spatial diversity. We compare age-specific migration patterns found in Russia and those observed in other developed countries. For this investigation, we mainly use Russian administrative data on residence registration for 2012-2016, together with information on populations by age in the latest census in 2010 . The data are analysed using a classification of local administrative units classified by degree of remoteness from Russia's principal cities (regional centres).

The main results are as follows: In Russia, young people participate strongly in migration flows between peripheral territories and regional centres. The net migration surplus in regional centres is mostly produced by the migration of 15-19 yearolds starting further and higher education courses. Peak migration occurs in this age group. This type of migration represents upward mobility in the spatial hierarchy because institutions of higher education are located in the large cities. People aged 20-29 and 30-39 migrate in much smaller numbers, but they also replenish the population of regional centres. The inflow of middle-aged migrants and families with children was directed to the areas located closest to the regional centres, the suburbs. This type of migration is observed in regions with a well-developed middle class with high purchasing power, for example, in the city of Moscow and in the Moscow Region.

Peripheral territories have similar profiles of age-specific migration, but of loss rather than gain. The farther they are from regional centres, the more significant the outflow of young people and the stronger the impact of migration on population ageing. The rural periphery and small cities attract only elderly migrants, but this inflow is far smaller than the outflow of young people. The directions and age
\end{abstract}

This article belongs to a special issue on "Internal Migration as a Driver of Regional Population Change in Europe: Updating Ravenstein". 
selectivity of migration observed in other countries are thus also found in Russia, although there are important differences associated with the nature of housing in Russian cities and regions.

Keywords: Internal migration $\cdot$ Russia $\cdot$ Net migration $\cdot$ Regional centres and periphery $\cdot$ Age

\section{Introduction}

Migration greatly contributes to the transformation of demographics at the regional and municipal level. Young people are traditionally the most mobile group. Ravenstein (1876) argued that in England and Wales, teenagers and single young adults accounted for the major share of migrants. In Russia, the results of the first population census conducted in 1897 similarly showed that single young peasants comprised the most numerous migrant group (Tihonov 1978).

The migration behaviour of young people has a major impact on many territories of arrival and departure in terms of their demographic characteristics. However, there are territories where the population structure is more dependent on the mobility patterns of working-age groups and elderly people. Such territories may specialise in certain manufacturing activities, have specific market functions, stand out as unique natural and climatic zones or have other important characteristics. We suggest that age-specific migration patterns should be analysed at lower levels of spatial hierarchy.

The consequences of the diverse factors influencing migration are more explicit at these levels rather than at the level of large regions, where the influence of one group of factors can be compensated or neutralised by other factors. For example, at the regional level, population growth compensates for the population decline as a result of migration exchange between centres and peripheries, between urban and rural areas, and between more developed and less developed municipalities.

Migration statistics on municipalities in Russia have been published open access since $2012 .{ }^{1}$ Analysing these data, we can understand a) how the age profile of net migration varies depending on the remoteness of a territory from the regional centre; and b) how the age profiles of migration of various types of regional centres and peripheral areas differ.

As in other countries, migration in Russia has been selective in terms of age and, most likely, in terms of destination. However, due to specific historical circumstances, as well as to the lack of open statistical data, these aspects of migration have been little studied. Only a few papers have addressed these issues (Rahmanova 1994; Moiseenko 2004). Therefore, it was hardly possible to speculate about pos-

1 Database on the municipal formation indicators http://www.gks.ru/free_doc/new_site/bd_ munst/munst.htm 
sible differences or similarities between Russia and other countries. With this paper we aim to fill this knowledge gap.

The remainder of this paper is organised as follows. We begin with an analysis of the academic discourse on age-specific migration patterns in different types of territories. We then describe our approach to the analysis of migration in regional centres and regional peripheries. We present the results of the analysis of the existing age structure of the population, age-specific patterns of net migration in centres and various types of peripheral areas. As a separate case, we analyse the Moscow agglomeration. Finally, we conclude the paper with a discussion of results and suggestions regarding further research.

\section{Previous research}

The migration relationship between centres and peripheries is a complex multilateral process no longer described as one-way movement and not considered as "effets de vases communicants" (Dasre et al. 2009). Depending on countries and regions, this process has various forms and scale. In the USSR, the difference between centres and peripheries was significant. However, at that time, the authorities took measures to constrain the growth of the largest cities. Therefore, population distribution between rural and urban areas was not motivated by the size of the cities. The stage of mature urbanisation took a long time because of the numerous turbulences of the $20^{\text {th }}$ century (Nefedova/Treivish 2003). After the dissolution of the USSR, the socio-economic discrepancies between the regions and within the territories increased, while the major administrative barrier of propisk ${ }^{2}$ was removed. These factors could have led to the intensification of population redistribution between centres, suburbs and peripheries. Moreover, this process could have been more intensive than in the countries where urbanisation and the centre-periphery relationship between territories underwent an evolutionary development.

Nowadays, the patchy distribution of the population in Russia is mostly the result of migration (Karachurina/Mkrtchyan 2015). The most noticeable elements are the regional centres. Usually, these are cities with a population of over 200,000 which attract migrants from the same region. The largest and more economically developed centres are also attractive for migrants coming from neighbouring regions (Karachurina/Mkrtchyan 2016; Zubarevich 2010). Moscow and St. Petersburg lead not only in terms of size but also in terms of economic prosperity, and serve as migration destinations for migrants from all over the country. Migration to these

2 Propiska is a residence registration system which required the official permission of authorities to register one's residence in the USSR, thus constraining the movement of people. In 1993, the rules changed, requiring people to simply notify the local authorities about the change of residence instead of obtaining special permission to do so. While major barriers to migration were removed, some restrictions remained: for example, if a person was not registered at the place of residence, she/he had limited access to social protection. 
destinations confirms that "migrants who move longer distances tend to choose major sources of economic activity" (Ravenstein 1885).

Most peripheral territories in Russia experience migration outflows. Very few of them have cities that serve as destinations for people coming from neighbouring areas, following the logic of the prevalence of short distance migration, as noted by Ravenstein $(1885,1889)$.

This stage of centre-periphery relationship development, when migration flows are directed to the centres, occurred in most developed countries decades ago (Berry 1980; Champion 1987; Geyer/Kontuly 1993). Unlike in Russia, the concentration of the population which resulted from migration can be found in urban centres in those countries but not necessarily in regional centres. For example, in Great Britain, young and vibrant cities stand out as areas with net migration surplus, against the general tendency of counter urbanisation (Dennett/Stillwel/ 2010).

In the countries of eastern Europe, the concentration of the population in large cities occurred later than in western Europe (Kupiszewski et al. 1998; Raagmaa 2003; Vobecka 2010). Currently, some eastern European countries are undergoing re-urbanisation as experienced in a number of urban districts in the countries of western Europe (Sander 2014; Haase et al. 2017). In contemporary Russia, migration to the centres still remains the key migration trend: the larger the centres, the more migrants move there (Nefedova/Treivish 2017; Zubarevich 2010).

Therefore, we can conclude that internal migration patterns are associated with the stages of urban development. At the initial stages of urbanisation, internal migration flows are directed only one way, resulting in the concentration of people in large city centres (Ravenstein 1885; Vining/Pallone 1982; Geyer/Kontuly 1993). At the later stages of urban development, alongside stronger economic diversification and the growing popularity of alternative places of residence (Berry 1980), and due to the greater variety of consumer preferences (Long/Deare 1988), migration flows start taking other directions. People move from cities to suburbs and to rural areas, as well as between cities of different size and type (Champion et al. 2014); not only up but also down the escalator (Fielding 1989, 1992), and up and down the urban hierarchy (de Jong et al. 2016). Migration trends in more densely populated territories differ from those in less populated areas (Stil/well et al. 1990; Rees et al. 1996). Migration patterns become more complicated and diverse in terms of the distribution of population across the territory of the country.

On the other hand, Bell et al. (2015), Bernard et al. (2014), Kalogirou (2005), Dennett/Stil/well (2010), Millington (2000) traced the link between migration patterns and life course events. They revealed that, across countries, the life course events driving migration may occur at different points in time and may vary in terms of duration. However, migration events are always linked to some stages of the life course.

Meanwhile, the research project conducted by the Council of Europe for several years reveals that the only common feature of age-specific migration profiles of the countries is the inflow of young people to large urban agglomerations (Rees/ Kupiszewski 1999). The migration of the young can be treated as an ordinary life course event. Fielding (1989, 1992; Savage/Fie/ding 1989) describes so-called esca- 
lator regions, where young ambitious people come to make use of the existing opportunities and then leave. Hansen and Niedomys/ (2009) show that the difference in the "people climate" between the place of birth/youth and prospective migration destinations is important to consider when analysing the migration of the young. Quite logically, such comparatively "better" cities become even more successful thanks to young immigrants (Berry/Glaeser 2005; Findlay et al. 2009; Fratesi 2014; Gordon et al. 2015; Winters 2011). Smaller cities, rural territories with fewer opportunities for a good education, fewer employment prospects, and little potential for social and economic growth are unable to retain their young population. That is why the outflow of young people from rural areas always exceeds the outflow from cities. Research conducted in Scotland demonstrates that the youth outflow from periphery areas can be significant (Gillies 2014). Argent and Walmsley (2008) showed that in Australia, migration distance and migration frequency depend on the remoteness of the rural peripheral areas from the centres. This is an indicative case for our research because in Australia we find a specific system of population distribution, like in Russia.

Other age groups do not demonstrate similarities in terms of migration destinations. The age groups are heterogeneous in terms of the reasons for and the objectives of migration: there is no common dominating motivation driving the migration of the middle-aged and the elderly. For example, de Jong et al. (2016) find that in the Netherlands, migrants aged 18-44 move between different levels of urban hierarchy in both directions: upwards when migrating to large cities, and downwards when going to smaller cities, and 70 percent of migrants aged 35-44 choose smaller cities as migration destinations. In France, the 23-33 age-group is the key contributor to suburbanisation, while in general, migration to the suburbs and rural areas increases with age (Détang-Dessendre et al. 2008). In the United States, and in many European countries, middle-aged married couples usually consider moving to the suburbs, especially after the birth of children (Plane/Jurjevich 2009). In case of Great Britain, people move from the suburbs to more rural areas, including seaside territories (Dennett/Stil/we// 2010).

Fuguitt and Heaton (1995) argue that fast developing areas are attractive destinations for migrants of all ages. Martel et al. (2013) find that escalator regions can draw not only young and highly qualified migrants but also people of pre-retirement age who are driven by the desire to ensure a decent standard of living after retirement. Ultimately, there is no single factor explaining why a family considers one place or another more comfortable to live in; the decision is based on complex interactions between family members and can be motivated by a change of job and housing (Clark/Withers 2007; Mulder 2006).

Numerous migration studies devoted to the "young elderly" are focused on their desire to leave large cities and move to areas with better environmental conditions and lower housing prices (Millington 2000; Raymer et al. 2007), while the "old elderly" want to return to a previous place of residence or move closer to their relatives (Litwak/Longino 1987; Rogerson et al. 1997). Détang-Dessendre et al. (2008) demonstrate that in France, the old elderly are more inclined to leave large cities, but widowhood makes them return to cities. Rerat et al. (2008) conclude that in the 
case of Switzerland, there is no evidence confirming that the old elderly return to cities in great numbers. In Denmark, the old elderly would prefer to move to the suburbs of Copenhagen where they find a better environment and good access to services (Kupiszewski et al. 2001).

In general, the periphery has a quieter lifestyle which is attractive for people of certain ages, habits and social capital (Blowers/Leroy 1994; Polèse/Shearmur 2006; Kauppila 2011; Pileček et al. 2013). Therefore, it is quite logical to suggest that a net migration surplus in the rural periphery - if any - is more likely to result from the migration of the elderly (Fuguitt/Heaton 1995; Philip et al. 2013); even for these people, a migration decision is the result of an interplay between life course events, economic factors and chance (Stockdale 2014).

These examples show that the choice of migration destination - be it a centre, suburb or peripheral area - varies for migrants of different age and at different life stages. Plane and Heins (2003) analysed the directions of migration across districts in the United States and identified clusters of territories based on the migration preferences of people from different age groups. Qualitative research findings more often indicate that such a standardised interpretation of migration (associated with life course events) simplifies reality (Kalogirou 2005; Plane et al. 2005; Stockdale 2014), and that the age-specific migration profile of the territories belonging to different levels of urban hierarchy is more complicated.

In the case of Russia, we observe even more complicated age-specific migration profiles. Most of Russia's territory is sparsely populated, even in the European part where most of the population is concentrated (Glezer/Vainberg 2014). The vast peripheral areas of Russian regions are still different in terms of the historically established structure of settlement networks (for example, small settlement pattern in the west of the country, large settlement pattern in the south, and fragmented settlement system in the north and north-east). Other differences concern the accessibility of the peripheral territories, the presence or lack of peripheral cities acting as local sub-centres, their size and economic potential. Finally, these territories are not equally attractive for young people, middle-aged and elderly people.

Age-specific migration in Russia has been studied at the country level (Moiseenko 2004) and at the level of large regions (Rahmanova 1994). Studies focusing on age-specific migration at the level of regions (Kashnitsky et al. 2016) and municipalities are quite recent (Karachurina/Mkrtchyan 2018). The objective of this paper is to investigate how the age-specific migration patterns observed in Europe and the United States are manifested in Russia considering its peculiar socio-historical development, and compares the age profiles of net migration in central and peripheral municipalities.

Such comparative analysis yields more meaningful insights than a comparison of large administrative areas of the country. Age profiles of net migration in the centres of various parts of the country have more similarities than those in centres and nearest peripheral territories. However, there are exceptions to this rule, and these equally deserve attention.

We analyse net migration in different types of territories (regional centres, various types of peripheral territories, differing in remoteness from regional centres) 
within the same level of urban hierarchy (to some extent, corresponding to NUTS-3 level). ${ }^{3}$ We aim to find differences in age-specific migration profiles of $\mathrm{MFs}^{4}$ of the regional centres and MFs of the periphery areas. Finally, we answer the question of whether the Russian migration model corresponds to the migration trends observed in developed countries, and we describe its peculiarities.

Unlike Plane and Heins (2003) and de Jong et al. (2016), we cannot use the data on migration flows between urban hierarchy levels. Our data compare the results of population redistribution using the net migration data for various age groups and types of territories - centres and peripheral areas.

\section{$3 \quad$ Methods and data}

Our research on age-specific net migration in Russia's MFs relies on the following:

- data on the age composition of the population in Russia's MFs derived from Russia's 2010 census;

- administrative data from the Russian Federal State Statistics Service concerning net migration by 5 -year age groups for intraregional, interregional and international migration flows for Russia's MFs for the period 2012-2016;

- administrative data from the Russian Federal State Statistics Service on the age composition (by 5-year age groups) of the population in Russia's MFs for the period 2012-2016.

We use migration data from administrative sources. These data are similar to the migration data derived from population registers for migration research in European countries (Bell et al. 2015). The number of migration events does not always coincide with the number of people who migrate, as of the end of the year. In our analysis we use the data on migrants' age for the year when migration occurred.

The data on migration inflows and outflows is available for almost all MFs of the regions of Russia starting in 2012 or 2013. However, the interpretation of the data at this level is a separate task which we envisage to complete in another research.

As of 1 January 2012, there were 83 regions in Russia (Appendix 1) divided into 2,334 MFs. This level of administrative-territorial units covered 517 urban okrugs and 1,817 municipal districts ${ }^{5}$ (Fig. 1). In Russia, urban okrugs mainly refer to cities,

3 NUTS system is not directly compatible the Russian administrative division system. With a considerable degree of conditionality, we can compare Russian regions and territories of the NUTS-2 level, as well as municipal formations (MFs) and territories of the NUTS-3 level by population size (Kashnitsky 2018).

4 Municipal formations in Russia are administrative territorial divisions with local self-government.

5 The list of the regions of Russia can be found in Appendix 1. MFs (city districts and municipal districts) which belong to a particular region are indicated in the Russian Federation Population by Municipal Districts as of 1 January 2012. Statistical Bulletin. Moscow. Rosstat 2013 [https:// gks.ru/compendium/document/13282]. 
Fig. 1: Method of categorisation of the centres and periphery in Russia at the two small administrative levels

Administrative level

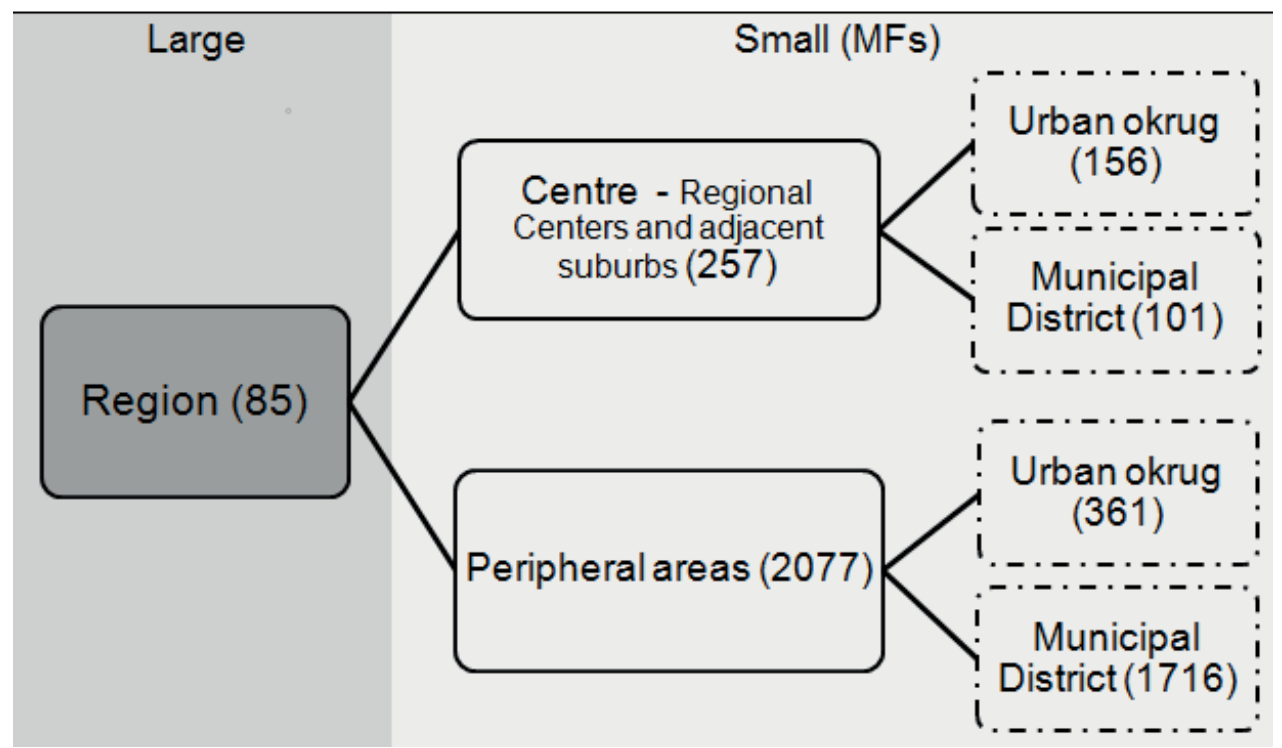

Note: Figures in brackets denote the number of units at the given administrative level

Source: Compiled by authors using "Rosstat 2013: The population of the Russian Federation by municipal formations as of January 1, 2012. Statistical Bulletin. Moscow"

although these areas sometimes include adjacent rural populations. Municipal districts are administrative divisions inhabited by both urban and rural populations, or by rural populations only. Data on 2,208 MFs - 94.6 percent of all MFs in the country (96.3 percent of the population) - were available for analysis. Information was not available on MFs in Dagestan, Kabardino-Balkaria, Tyva, Chukotsky Autonomous Okrug and closed administrative-territorial units (CATUs). The total population size of the MFs not covered in our research is 5.4 million people (the population of the CATUs is 1.2 million).

The federal cities of Moscow and St. Petersburg and other large cities were analysed without further division into intra-urban municipal territories because, in Russia, the change of place of residence within a city is not considered a migration event.

For the purposes of our analysis, we divide all municipal formations into "Centres" and "Periphery MFs". "Centres" include capital cities of regions and the suburban MFs surrounding these centres. If a regional centre borders more than one MF (and the centre is located at the intersection of MFs), these MFs are considered as belonging to the centre (Fig. 2). The remaining MFs in each region are treated as peripheral (See: Mkrtchyan 2019). 
Fig. 2: Method of categorisation of the centres composed of a regional centre and adjacent suburbs

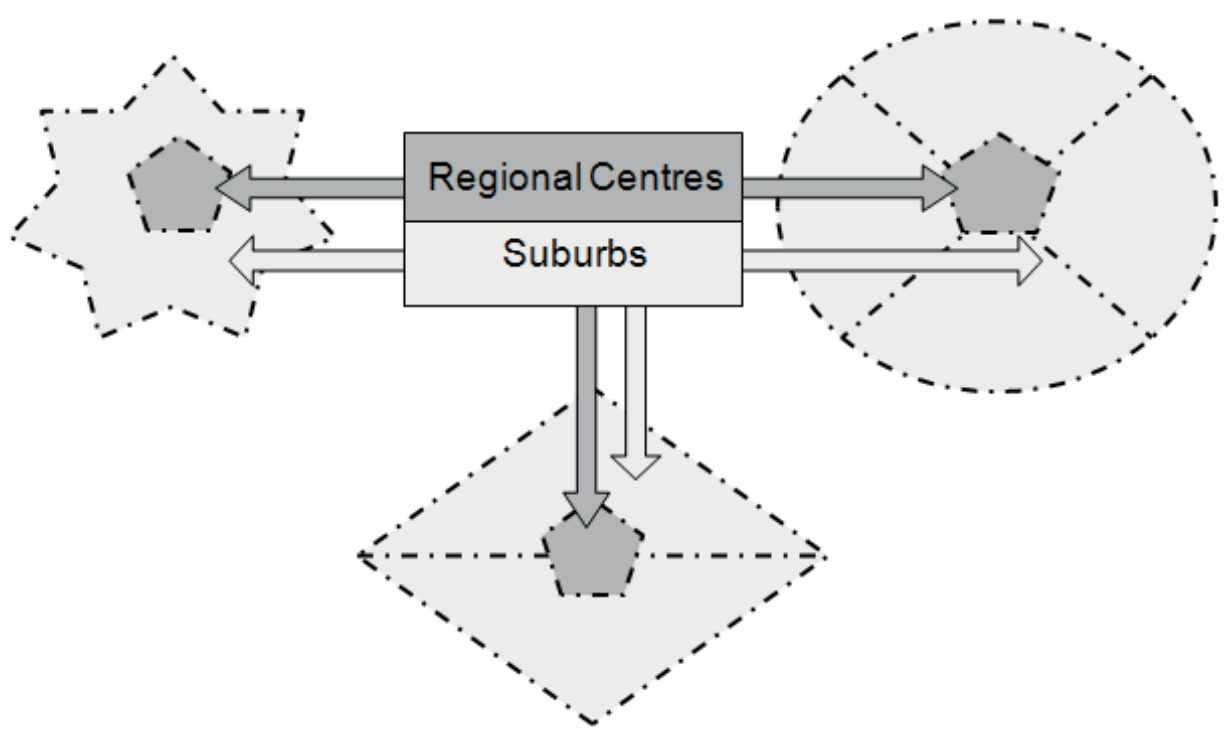

Source: own design

For our analysis, we divided peripheral areas into categories based on the criteria of physical and conventional remoteness from the centre. Physical remoteness is the distance between an MF and the regional centre, measured in kilometres using existing transport routes. Conventional remoteness is denoted by ranks of remoteness from a regional centre. Centres and adjacent suburbs are MFs of the zero rank (Fig. 3). Those MFs that are adjacent to the central MFs are considered first-rank MFs, while those adjacent to first-rank MFs are MFs of second rank, and so on to MFs of the fifth and higher ranks. Such ranking allows us to compare areas of Russian regions of different size. For example, fifth rank of remoteness - regardless of the level of development - is a remote periphery, although it may be located $100 \mathrm{~km}$ or $250 \mathrm{~km}$ away from a regional centre.

A time criterion could be used to measure the distance of migration. However, we do not have the relevant data for all regions and MFs in Russia. In addition, in the case of Russia, physical distance closely correlates with temporal accessibility, except for the suburbs of Moscow and St. Petersburg: these areas benefit from a well-developed public transport network and a dense motorway network. For example, a two-hour temporal accessibility to a regional centre would correspond to the same measure of spatial accessibility in most Russian regions because the road infrastructure in the regions provides similar time options for distance coverage (Neretin 2018; Neretin et al. 2019). 
Fig. 3: $\quad$ Method of categorisation of the periphery areas by rank of remoteness from the centre

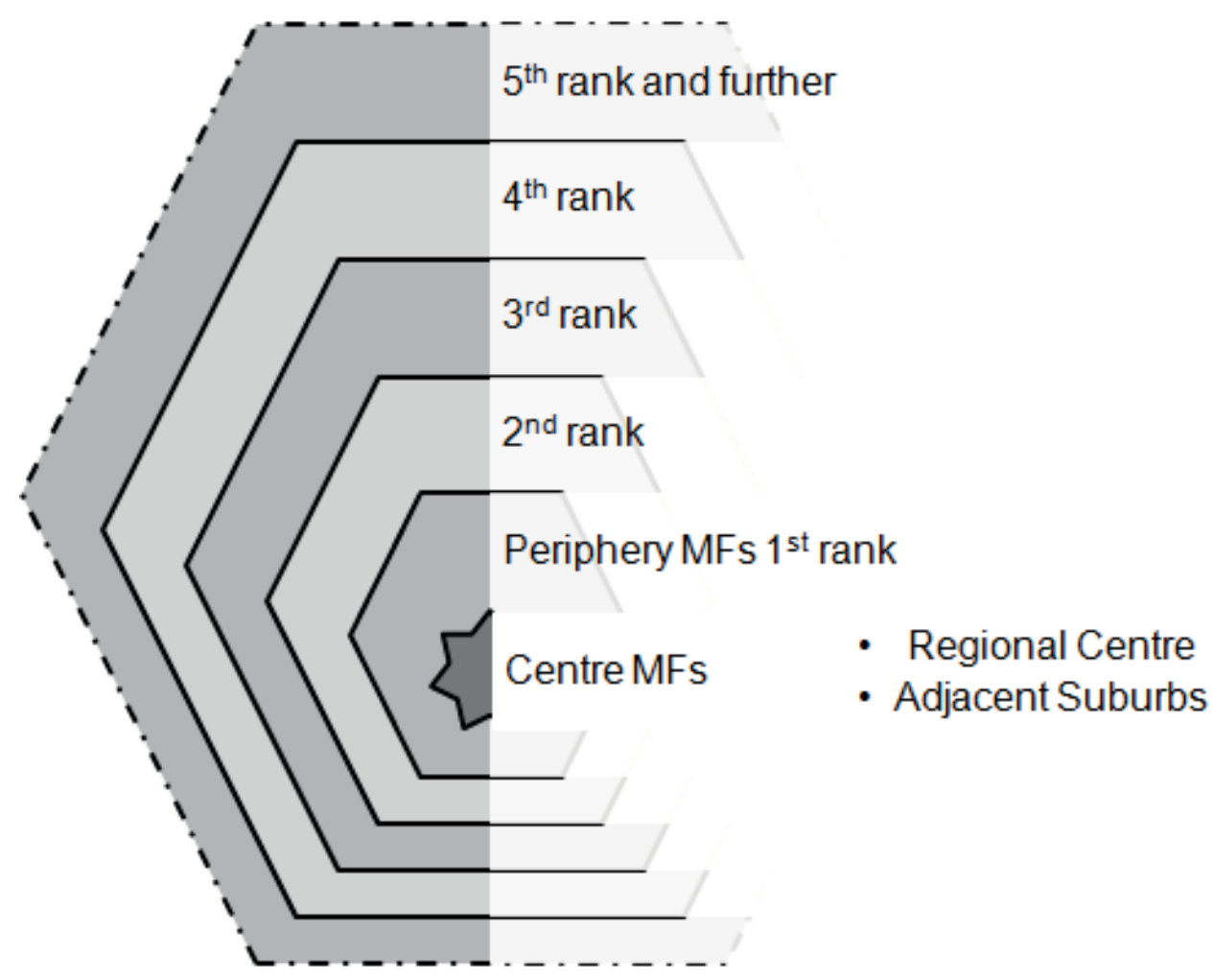

Source: own design

The main variable used in the analysis is net migration by 5 -year age groups ${ }^{6}$ per 1,000 people of the corresponding age calculated for all MFs as an average for the period 2012-2016.

Analysis of the MF-specific net migration by 5-year age groups allows us to determine which migration flows (intraregional, interregional or international flows) contribute to the net migration surplus or deficit in each MF. Tabulation of migration flows by age and scale of migration enables us to determine how important intraregional, interregional and international migration flows are at each life course stage.

Thus, we combine the age-specific dimension of migration with a specific classification of territorial units, which allows us to differentiate between MFs by migration indicators. We also use Russia's population census data of 2010 to compare the age composition of populations in centres and peripheral areas.

6 The age groups are 0-4 years (including children aged under 1 who were born in the year of migration), 5-9 years. $10-14$ years, $15-19$ years and so on. 


\section{$4 \quad$ Results}

\subsection{Age composition of the population in the centres and peripheral areas}

The age compositions of the population in central and peripheral MFs are not similar. Central MFs have a larger share of young people and working-age population (in Russia, working age is defined in legislation as 15-54 years for women and 15-59 years for $\mathrm{men}^{7}$ ). Peripheral areas have a larger share of children, but the share of elderly people is almost the same (Table 1). These differences result from different birth rates in large cities (most of them are regional centres) and rural areas (which make up the major part of the peripheral areas). In rural areas, the birth rate is still higher (Vishnevskij 2014); therefore, in peripheral MFs, the number of children is greater, although the number of people of reproductive age (20-49 years) is lower than in the regional centres.

Tab. 1: Age structure of the population in centres and peripheral MFs in Russia, $2010, \%$

\begin{tabular}{|c|c|c|c|c|c|c|c|c|}
\hline \multirow[t]{2}{*}{$\begin{array}{l}\text { Age } \\
\text { group }\end{array}$} & \multirow[t]{2}{*}{$\begin{array}{l}\text { Total } \\
\text { population }\end{array}$} & \multirow[t]{2}{*}{ Centres } & \multirow[t]{2}{*}{$\begin{array}{l}\text { Periphery } \\
\text { MFs }\end{array}$} & \multicolumn{5}{|c|}{$\begin{array}{l}\text { Proximity of periphery areas to the } \\
\text { regional centre }\end{array}$} \\
\hline & & & & $\begin{array}{c}1^{\text {st }} \\
\text { rank }\end{array}$ & $\begin{array}{l}2^{\text {nd }} \\
\text { rank }\end{array}$ & $\begin{array}{c}3^{\text {rd }} \\
\text { rank }\end{array}$ & $\begin{array}{c}4^{\text {th }} \\
\text { rank }\end{array}$ & $\begin{array}{c}5^{\text {th }} \text { rank } \\
\text { and beyond }\end{array}$ \\
\hline $0-4$ & 5.6 & 5.1 & 6.0 & 6.1 & 5.9 & 5.9 & 5.9 & 6.1 \\
\hline $5-9$ & 5.0 & 4.5 & 5.3 & 5.4 & 5.3 & 5.3 & 5.3 & 5.5 \\
\hline $10-14$ & 4.6 & 4.1 & 5.1 & 5.0 & 5.1 & 5.1 & 5.2 & 5.4 \\
\hline $15-19$ & 5.9 & 6.0 & 5.7 & 5.8 & 5.8 & 5.7 & 5.7 & 5.7 \\
\hline $20-24$ & 8.5 & 9.2 & 7.9 & 8.2 & 7.9 & 7.7 & 7.7 & 7.5 \\
\hline $25-29$ & 8.4 & 9.0 & 7.9 & 8.1 & 7.9 & 7.7 & 7.7 & 7.7 \\
\hline $30-34$ & 7.7 & 8.1 & 7.3 & 7.5 & 7.3 & 7.2 & 7.2 & 7.3 \\
\hline $35-39$ & 7.1 & 7.3 & 6.9 & 7.0 & 6.9 & 6.9 & 6.8 & 7.0 \\
\hline $40-44$ & 6.5 & 6.5 & 6.4 & 6.4 & 6.4 & 6.4 & 6.4 & 6.5 \\
\hline $45-49$ & 7.5 & 7.3 & 7.6 & 7.5 & 7.6 & 7.7 & 7.8 & 7.8 \\
\hline $50-54$ & 8.0 & 7.7 & 8.3 & 8.1 & 8.3 & 8.4 & 8.5 & 8.6 \\
\hline $55-59$ & 7.0 & 6.8 & 7.2 & 7.1 & 7.2 & 7.2 & 7.3 & 7.2 \\
\hline $60-64$ & 5.5 & 5.6 & 5.3 & 5.3 & 5.4 & 5.4 & 5.3 & 5.1 \\
\hline $65-69$ & 2.8 & 2.9 & 2.7 & 2.7 & 2.7 & 2.8 & 2.7 & 2.6 \\
\hline $70-74$ & 4.5 & 4.4 & 4.6 & 4.4 & 4.6 & 4.8 & 4.6 & 4.4 \\
\hline $75-79$ & 2.5 & 2.3 & 2.6 & 2.5 & 2.6 & 2.7 & 2.7 & 2.6 \\
\hline $80-84$ & 2.0 & 1.9 & 2.1 & 2.0 & 2.1 & 2.2 & 2.2 & 2.1 \\
\hline $85+$ & 1.0 & 1.0 & 0.9 & 0.9 & 0.9 & 0.9 & 0.9 & 0.9 \\
\hline Total & 100.0 & 100.0 & 100.0 & 100.0 & 100.0 & 100.0 & 100.0 & 100.0 \\
\hline
\end{tabular}

Source: Authors' computations using Russia's 2010 Census [https://www.gks.ru/free_doc/ new_site/perepis2010/croc/perepis_itogi1612.htm]

7 This retirement age was set in Russia in 1932 (based on the low life expectancy rates) and remained as such until 2018. 
The birth rate in large cities is lower than in the peripheral areas, but due to the inflow of young people, the age structure becomes younger. The shares of middleaged people and the elderly in the centres and peripheral areas are almost equal.

On the one hand, Rees et al. (2017) point out to the "high migration effectiveness" in Russia which could lead to significant differences in age composition of the population in centres and periphery MFs. On the other hand, the consequence of the "high migration effectiveness" could be the convergence between centres and periphery areas, due to the higher birth rate and younger age structure of the periphery. In any case, the centres benefit from the migration inflow of the young.

\subsection{Age profiles of migration flows in the centres and peripheral areas}

Regional centres and peripheral areas have different age-specific net migration profiles for all types of migration flows (Table 2). Only international migrants contribute to the net migration surplus both in centres and peripheral MFs. However, the intensity of international migration inflow in centres is higher than in peripheral MFs. For intraregional and interregional migration, centres and peripheries differ substantially. In other words, a net migration surplus is observed only in the centres, while peripheral areas suffer from a net migration deficit.

The redistribution of the population between the centres and peripheral MFs is mainly driven by the movement of young and middle-aged people (Fig. 4). The highest migration peak in the 15-19 age group is observed in intraregional migration. This peak is driven by educational migration, ${ }^{8}$ with the main inflow being directed toward regional centres from other cities of the same region and from rural areas.

Tab. 2: Net migration in the regional centres and peripheral MFs, by various types of migration flows, average for the period 2012-2016, per 1,000 people

\begin{tabular}{lc|ccc}
\hline & $\begin{array}{c}\text { Total } \\
\text { migration }\end{array}$ & $\begin{array}{c}\text { Including } \\
\text { Intraregional } \\
\text { migration }\end{array}$ & $\begin{array}{c}\text { Interregional } \\
\text { migration }\end{array}$ & $\begin{array}{c}\text { International } \\
\text { migration }\end{array}$ \\
\hline Regional centres & 9.4 & 3.9 & 2.9 & 2.7 \\
Peripheral MFs ${ }^{*}:$ & -2.9 & -2.8 & -1.9 & 1.8 \\
$1^{\text {st }}$ rank & 1.2 & -1.3 & 0.4 & 2.1 \\
$2^{\text {nd }}$ rank & -3.3 & -3.1 & -2.2 & 2.0 \\
$3^{\text {rd }}$ rank & -5.0 & -3.6 & -2.8 & 1.4 \\
$4^{\text {th }}$ rank & -5.3 & -3.5 & -3.0 & 1.2 \\
$5^{\text {th }}$ rank and higher & -7.2 & -4.2 & -4.4 & 1.3 \\
\hline
\end{tabular}

${ }^{*}$ by rank of proximity to the regional centre

Source: Authors' computations using Russian Statistical Office, Municipal Formations Database (MFD) [https://www.gks.ru/storage/mediabank/munst.htm]

8 It is very common in Russia that 80 percent of school graduates (after 11th grade) choose to continue studying after school (Bessudnov et al. 2017). 
Fig. 4: Net migration (surplus or deficit) in the centres and in periphery MFs, by types of migration flows and age groups, average for the period 20122016, per 1,000 people of the corresponding age

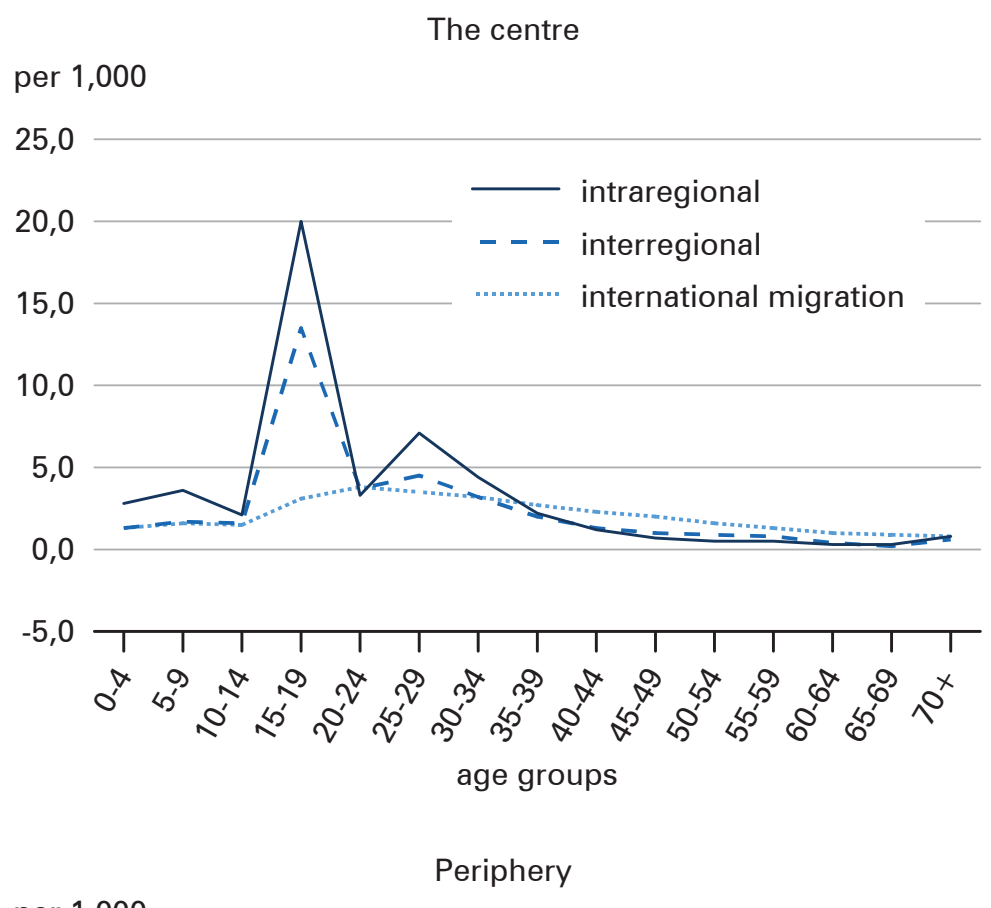

per 1,000

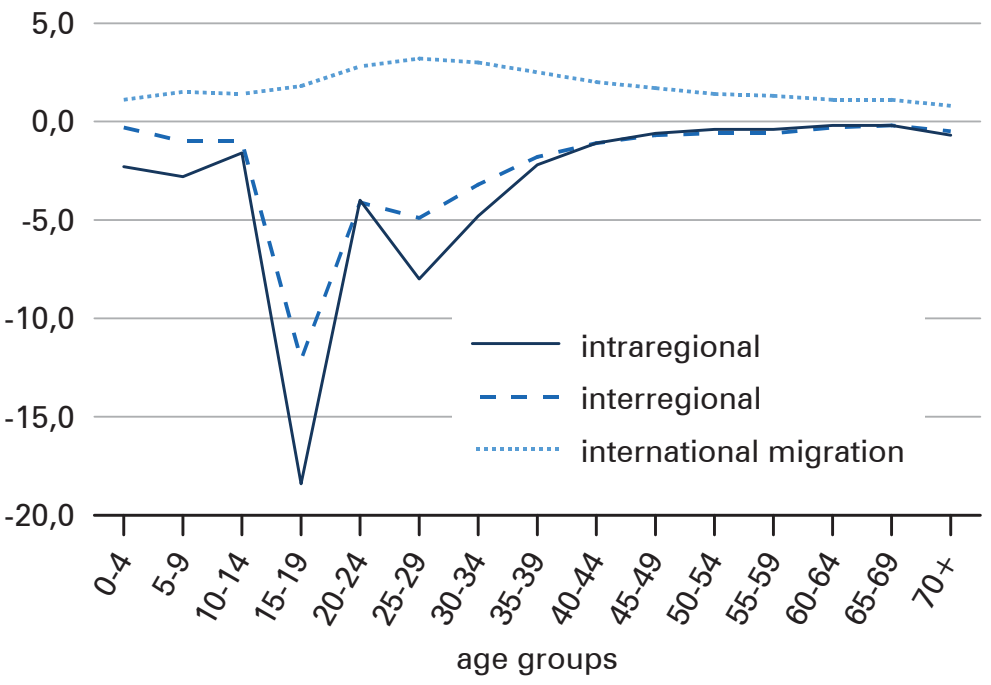

Source: Authors' computations using Russian Statistical Office, Municipal Formations Database (MFD) [https://www.gks.ru/storage/mediabank/munst.htm] 
Young people migrate from remote rural settlements and small cities to the regional centre to gain higher educational or technical qualifications and as a way to escape their native settlements (Karachurina/Florinskaya 2019; Endryushko 2018). This is a very popular strategy. The age profile of interregional migration is smoother because the flow is composed of both educational migrants and young people who relocate after graduation in search of jobs (20-29 age group). International migration has the smoothest age profile: a migration peak is observed in the 25-29 age group and this inflow is not associated with education.

In Russia, life course events such as graduation from school, enrolment in university and graduation from university have clear connections to specific ages; therefore, the migration to centres which provide higher university or technical education that happens at a certain age produces a noticeable impact on migration flows. Here, the peaks of migration are higher than in many developed countries where the life trajectories of people are more diverse and life-course events have a less strict connection to age (Billari/Liefbroer 2010; Bernard et al. 2014, 2016).

All peripheral MFs experience an out-migration of student-age populations who move to regional centres (Fig. 5). In Russia, large universities that are attractive to students can only be found in regional centres, with rare exceptions (the cities of Surgut, Novokuznetsk, Sochi and a small number of other large cities which are not capitals of the regions). Young people tend not to return to their origin MFs but instead find jobs and partners in the destination centres or equivalent centres (Kashnitsky 2018; Zamjatina/Jashunskij 2012).

\subsection{Age-specific migration processes in the Moscow agglomeration}

The differentiation between centres and peripheries is important because it helps explain the direction and composition of migration flows. Other factors should not be ignored either. For example, migration in MFs within the largest Russian agglomeration does not exactly correspond to the scheme describing the relationship between the centre and periphery of regions. For instance, all MFs within Moscow Oblast (region), regardless of how remote they are from the city centre, are popular destinations for migrants from other regions of the country. This is a manifestation of the centre-periphery relationship at the country level rather than at the regional level. A similar pattern is observed in the Leningrad Oblast (the St. Petersburg agglomeration). Immigration flows to Moscow, St. Petersburg and to the Moscow Oblast and the Leningrad Oblast from other regions of the country were also quite significant during the Soviet era. After the dissolution of the Soviet Union, this migration inflow intensified due to the disappearance of previous administrative barriers (Zajonchkovskaya/Mkrtchyan 2009).

When compared by the net migration rate, MFs adjacent to the centre of the largest agglomeration in Russia (Moscow) surpass the capital (Table 3). This phenomenon is the result of two independent processes:

1) The capital of Russia, just like other large cities of the country, is prone to "urban sprawl". Blocks of multi-storey buildings in districts close to Moscow make these areas look exactly like Moscow-city districts or the Moscow sub- 
Fig. 5: $\quad$ Net migration (surplus or deficit) in the periphery MFs of varying remoteness from the centres, by age groups, average for the period 2012-2016, per 1,000 people of the corresponding age

\section{Intraregional migration}

per 1,000

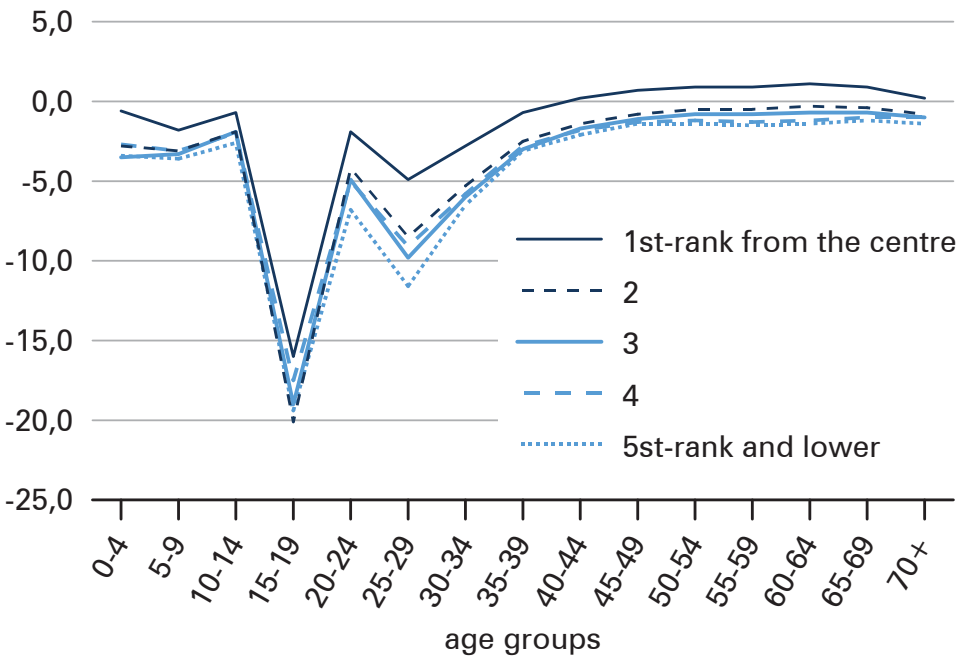

per 1,000

Interregional migration

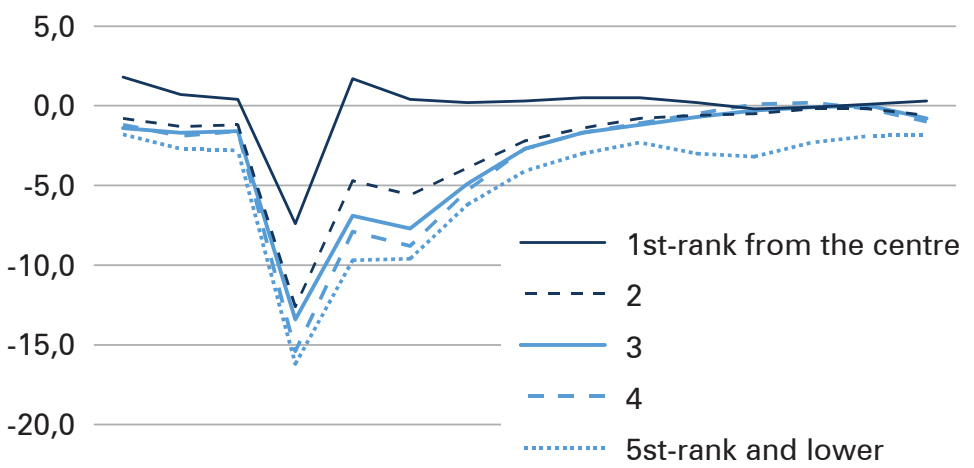

$-25,0$

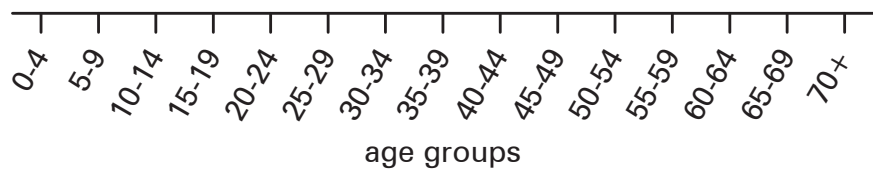

Source: Authors' computations using Russian Statistical Office, Municipal Formations Database (MFD) [https://www.gks.ru/storage/mediabank/munst.htm] 
urbs. This process, however, hardly resembles the development of low-storey suburbs observed in other countries. The case of Moscow qualifies as another stage of the classic process of urbanisation. The new multi-storey buildings attract interregional migrants and those residents of Moscow who wish to have an additional apartment or to move to a larger apartment ( $K u$ richev/Kuricheva 2018; Kuricheva/Popov 2015). Housing in the cities adjacent to Moscow is less costly than in the centre of Moscow.

2) As in the suburbs of cities in developed countries (Miller 1995; Kupiszewski et al. 1998; Champion/Hugo 2004; Kladivo et al. 2015), in Russian agglomerations, we observe a growing number of more comfortable and eco-friendly villages of two- and three-storey houses and townhouses owned by affluent people. However, Russian suburbanisation has its peculiarities in that the owners of suburban housing do not relocate from the capital to the suburbs; they prefer to live in both places, which is not reflected in the migration statistics of the Moscow Oblast.

Tab. 3: Net migration (surplus or deficit) in Moscow and in MFs of Moscow Region, by types of migration flows, average for the period 2012-2016, per 1,000 people

\begin{tabular}{lcccc}
\hline & $\begin{array}{c}\text { Migration, } \\
\text { total }\end{array}$ & $\begin{array}{c}\text { Intraregional } \\
\text { migration }\end{array}$ & $\begin{array}{c}\text { Including } \\
\text { Interregional } \\
\text { migration }\end{array}$ & $\begin{array}{c}\text { International } \\
\text { migration }\end{array}$ \\
\hline Moscow & 7.1 & 0.0 & 6.1 & 1.0 \\
MFs of the Moscow region, by remoteness from the centre of Moscow & \\
$<30$ & 27.0 & 1.7 & 22.2 & 3.1 \\
$30-50$ & 24.9 & 3.1 & 17.7 & 4.0 \\
$50-75$ & 8.5 & -1.9 & 7.7 & 2.7 \\
$75-100$ & 3.5 & -1.4 & 2.9 & 2.0 \\
$>100$ & 1.3 & -3.1 & 2.4 & 1.9 \\
\hline
\end{tabular}

* remoteness from Moscow is calculated using the administrative borders of Moscow before its expansion in 2012

** Migration between Moscow and the Moscow region is considered an interregional type of migration

Source: Authors' computations using Russian Statistical Office, Municipal Formations Database (MFD) [https://www.gks.ru/storage/mediabank/munst.htm]

What makes the net migration pattern in the suburban MFs of the Moscow Oblast peculiar is the absence of student-age migrant inflows (Fig. 6). Very few higher education institutions can be found in the Moscow Region, and student dormitories, as a rule, are also located in Moscow. Similarly, significantly fewer migrants of early retirement age - in comparison with Moscow - contribute to the net migration surplus in the Moscow Oblast. The capital is more attractive for this category of the population because of the substantial additional payments to pensioners from the city budget. This factor prevents pensioners from moving out of the capital to other regions of Russia, even to the Moscow Oblast. In the event that such migration does 
Fig. 6: Net migration (surplus or deficit) in Moscow and territories of the Moscow region, by age-groups, average for the period of 2012-2016, per 1,000 people of the corresponding age

per 1,000

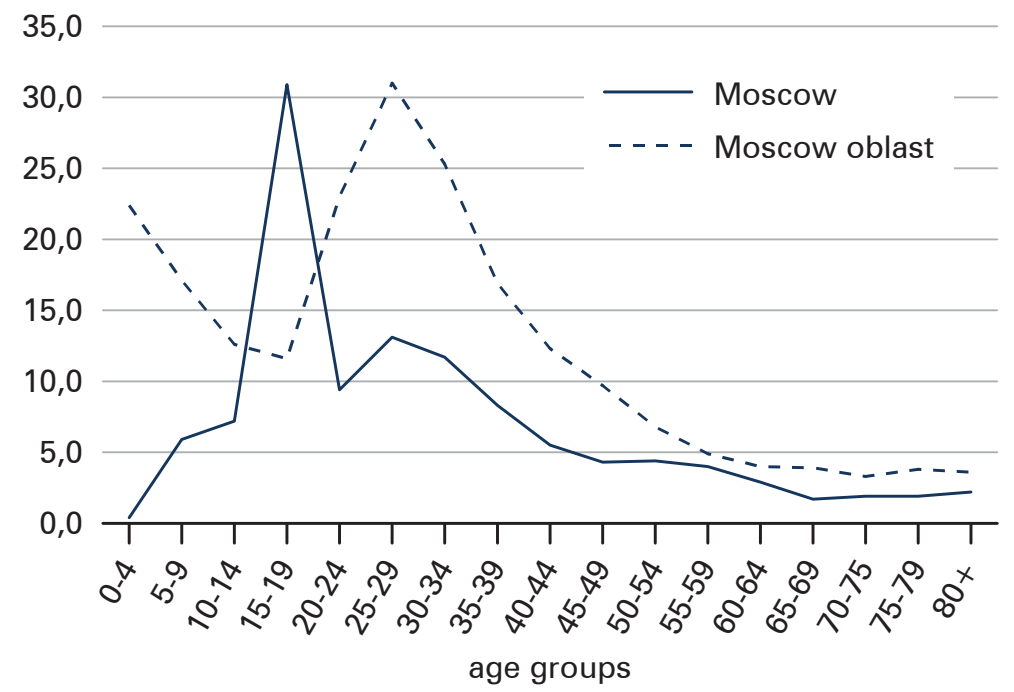

Source: Authors' computations using Russian Statistical Office, Municipal Formations Database (MFD) [https://www.gks.ru/storage/mediabank/munst.htm]

take place, it is not reflected in the statistical data since people do not cancel their Moscow registration so as not to lose pension-associated payments and healthcare services in Moscow (Karachurina/lvanova 2019).

Resettlement to the Moscow Oblast seems appealing to families with children. Our data show a significant net migration surplus observed in the 0-4 and 5-9 age groups (Fig. 3). This phenomenon is relatively new to Russia and is explained by the increased effective demand for new housing in the 2000s and by a greater choice of such housing in the Moscow Oblast than in the city of Moscow. Thus, the 25-39 age group of the population in Russia demonstrates migration patterns similar to those of the same age group in the United States or European countries (when young families with children move from the city to the suburbs) (Morrill 1995; Smetkowski 2011; Kley 2011), although the reasons for this migration are not associated with more attractive ecology or the prestige of these territories (Makhrova/Kirillov 2015; Mkrtchyan 2015).

\subsection{The age composition of migration in peripheral cities of various sizes and in rural areas}

Peripheral areas of Russian regions differ both in terms of their remoteness from the centres and in terms of having or lacking MFs that serve as local migration destinations. Such local destinations include, for example, large cities (with a population 
size of 100,000 or more) and mid-sized cities $(50,000-100,000$ people). In addition to urban settlements of different sizes, such MFs also include rural populations. ${ }^{9}$ To determine peripheral MFs with and without urban centres of different population sizes, we chose an indicator of the urban population share in the total population. Class 1 (see Table 4, Fig. 7) includes cities with a population that almost equals the population size of the corresponding MF. In other classes, the urban population ac-

Fig. 7: $\quad$ Centres and peripheral areas by classes

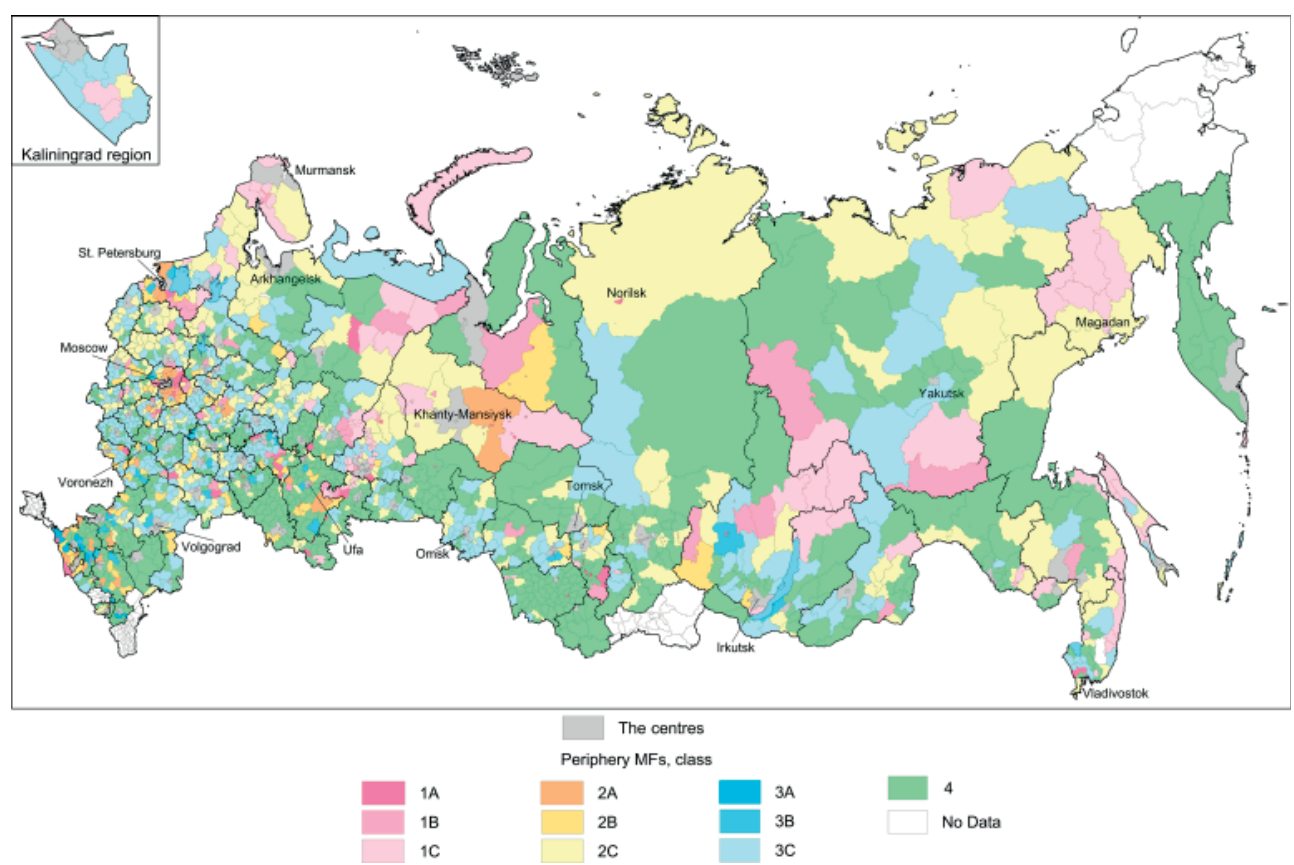

Note: Classes of the peripheral areas correspond to those in table 4.

The data on migration in MFs in four regions of Russia (the Dagestan Republic, the Kabardino-Balkar Republic, the Tuva Republic and Chukotka Autonomous Okrug), as well as migration data on towns and settlements belonging to the category of the closed administrative-territorial formations were not included into the MFD and were not available for the analysis.

** Closed administrative-territorial formations have functions associated with national security and defense. The statistical data on migration in these formations are not published in open access.

*** We use Asia North Equal Area Conic (ESPG: 102025) projection

Source: Authors' computations using Russian Statistical Office, Municipal Formations Database (MFD) ]https://www.gks.ru/storage/mediabank/munst.htm]

9 Unfortunately, existing statistical data do not allow us to distinguish cities within urban districts. 


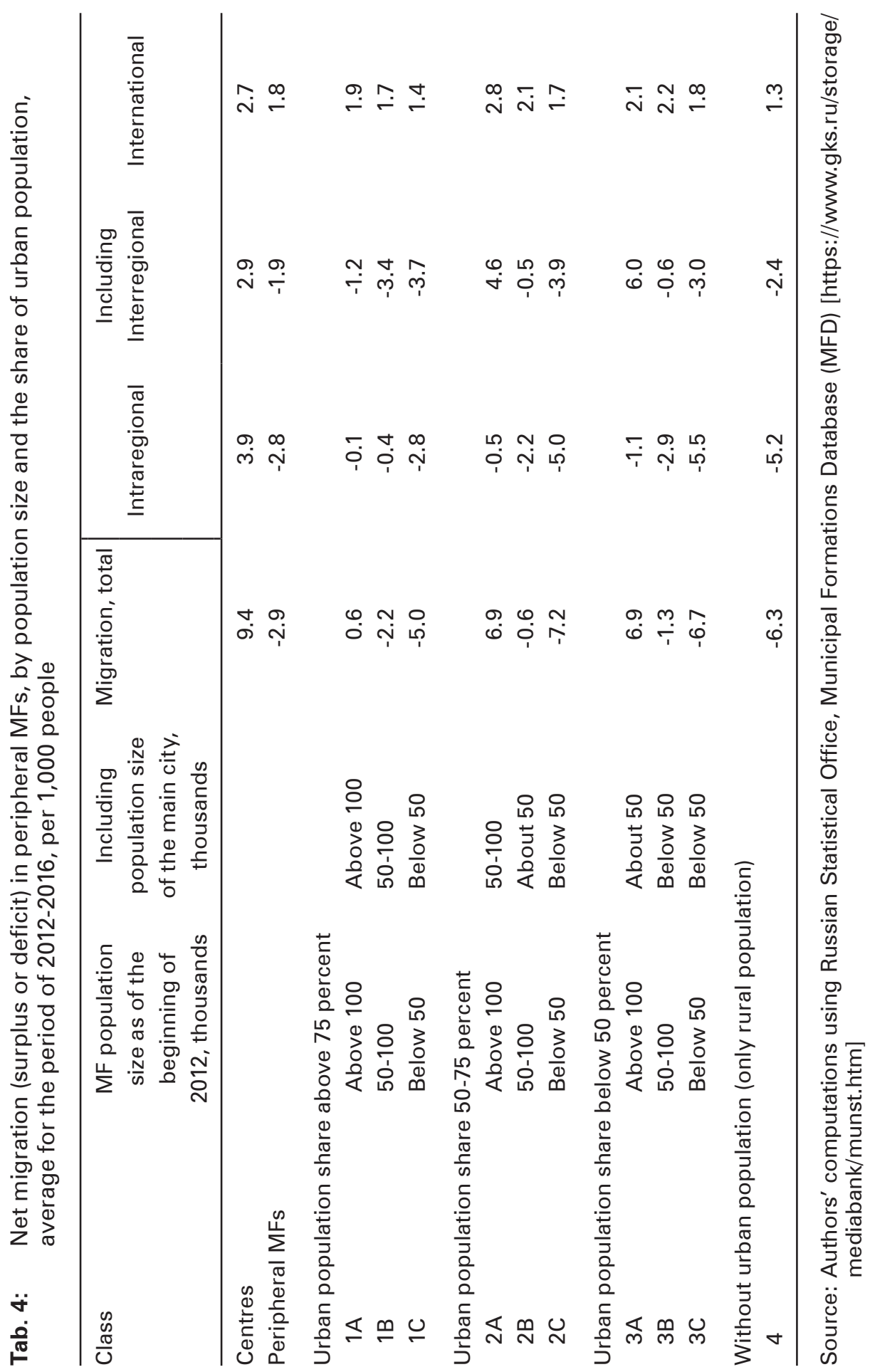


counts for either a major (Class 2) or minor (Class 3) share of the total population. Class 4 is composed of municipal districts with an entirely rural population. Letters $A, B$ and $C$ serve to denote the population size of a given MF.

In Russia, peripheral cities with larger population sizes experience less significant outflows of people. In total, net migration to the cities with a population above 100,000 people and located very far from regional capitals is almost zero (Class 1A). Such cities become centres and attract some migrants from adjacent MFs. These cities also tend to lose population because of out-migration to the regional centre (intraregional migration) or to a large neighbouring centre (interregional migration). Such cities, even large ones, are less attractive destinations for educational migration compared to regional centres due to their limited educational infrastructure. Hence, young people in the 15-19 age group usually move out. Unlike regional centres, these centres have a less diversified labour market, with economies dominated by single companies and manufacturing. Thus, these cities strongly depend on the financial and economic wellbeing of city-forming enterprises and industries, and they do not possess a permanent attractiveness as migration destinations (for example, the city of Toliatti is dependent on the automobile plant, and Novokuznetsk and Nizhniy Tagil depend on steelmaking plants).

Apart from industrial cities, the category of mid-sized cities (Class 1B, Class 2A in Table 4) also includes the cities of Moscow and Leningrad regions. These act as "peripheries" within their regions but as "centres" for interregional migration inflows, which helps ensure a net interregional migration surplus. Further, other attractive migration destinations among mid-sized cities are resort cities located on the coast of the Black Sea and in the region of the Caucasian Mineral Waters.

Some large (Class 1A) and medium-sized cities (Class 1B, Class 2A) with lucrative employment opportunities attract young professionals (20-29 years old). Such cities can be found in the oil- and gas-producing regions of the Urals, which are attractive for interregional migrants. People of pre-retirement and retirement ages move out of these cities. The inflow of young people and the outflow of the elderly produce positive demographic changes ("rotation") in these cities.

Peripheral MFs with a purely rural population and small cities with a population under 50,000 inhabitants (categorised under Classes 1C, 2B, 2C, 3A, 3B, 3C, 4 in Table 4) experience the highest population outflow. Rural peripheries and small peripheral cities are primary migration donors for regional centres in intraregional migration. These peripheral areas are unable to lure either educational migrants (there are no higher education institutions, and the capabilities of technical colleges can only satisfy local demand) or middle-aged people because of the limited employment opportunities and low wages. Many rural peripheral areas have poor transport links to regional centres and provide insufficient social services for their population (e.g. schools and healthcare), even in comparison with other peripheral MFs. Migration inflows to these cities can be explained by the return of people of pre-retirement and retirement ages, the low cost of housing, and a desire to escape from a large city.

For these rural and semi-rural areas, the relationship between net migration and the degree of remoteness from the regional centre is evident: the further the 
distance from the regional centre, the greater the migration outflow. Negative net migration is increasing both for intraregional and interregional migration (Table 5).

Analysis of variance (ANOVA) shows that the intensity of net migration in rural and semi-rural areas statistically differs at a 1-percent level of significance for areas similarly remote from the centre. Additionally, 9.5 percent of intraregional variance and 4 percent of interregional migration is explained by the scatter of the selected categories depending on their remoteness from a regional centre.

International immigration in Russia is mostly represented by the inflow of migrants from countries which were formally members of the Soviet Union, such as Ukraine or Kazakhstan. These immigrants find periphery areas are also attractive destination options: in the farthest periphery, one can purchase housing cheaply and obtain residential registration without actually living in the acquired property. In rural settlements with few inhabitants, the price of such housing is much lower

Tab. 5: Net migration (surplus or deficit) in rural MFs and small peripheral cities $^{*}$ by rank of remoteness from regional centres, average for the period of 2012-2016, per 1,000 people

\begin{tabular}{|c|c|c|c|c|}
\hline $\begin{array}{l}\text { Rank of remoteness of } \\
\text { a peripheral MF from a } \\
\text { regional centre }\end{array}$ & $\begin{array}{c}\text { Total } \\
\text { migration }\end{array}$ & $\begin{array}{l}\text { Intraregional } \\
\text { migration }\end{array}$ & $\begin{array}{l}\text { Including } \\
\text { Interregional } \\
\text { migration }\end{array}$ & $\begin{array}{c}\text { International } \\
\text { migration }\end{array}$ \\
\hline \multicolumn{5}{|c|}{ Share of urban population $50-75$ percent } \\
\hline $1^{\text {st }}$ rank & -2.3 & -2.9 & -1.5 & 2.0 \\
\hline $2^{\text {nd }}$ rank & -4.2 & -3.6 & -2.8 & 2.2 \\
\hline $3^{\text {rd }}$ rank & -6.5 & -3.8 & -4.0 & 1.3 \\
\hline $4^{\text {th }}$ rank & -6.4 & -4.1 & -3.6 & 1.3 \\
\hline $5^{\text {th }}$ rank and higher & -7.0 & -4.1 & -4.2 & 1.3 \\
\hline \multicolumn{5}{|c|}{ Share of urban population below 50 percent } \\
\hline $1^{\text {st }}$ rank & -5.4 & -5.0 & -2.1 & 1.6 \\
\hline $2^{\text {nd }}$ rank & -3.6 & -5.1 & -0.4 & 2.0 \\
\hline $3^{\text {rd }}$ rank & -6.0 & -5.4 & -2.4 & 1.8 \\
\hline $4^{\text {th }}$ rank & -8.0 & -6.4 & -3.5 & 1.9 \\
\hline $5^{\text {th }}$ rank and higher & -1.0 & -1.2 & -1.4 & 1.5 \\
\hline \multicolumn{5}{|l|}{ Only rural population } \\
\hline $1^{\text {st }}$ rank & -0.8 & -1.1 & -1.3 & 1.5 \\
\hline $2^{\text {nd }}$ rank & -7.2 & -6.1 & -2.4 & 1.3 \\
\hline $3^{\text {rd }}$ rank & -8.3 & -6.7 & -2.7 & 1.2 \\
\hline $4^{\text {th }}$ rank & -7.9 & -6.3 & -2.8 & 1.2 \\
\hline $5^{\text {th }}$ rank and higher & -10.1 & -7.6 & -3.4 & 1.0 \\
\hline
\end{tabular}

${ }^{*}$ Classes 1C, 2B, 2C, 3A, 3B, 3C, 4 in Table 4.

Source: Authors' computations using Russian Statistical Office, Municipal Formations Database (MFD) [https://www.gks.ru/storage/mediabank/munst.htm] 
Fig. 8: Net migration (surplus or deficit) in various classes of MFs, by age groups, average for the period of 2012-2016, per 1,000 people of the corresponding age

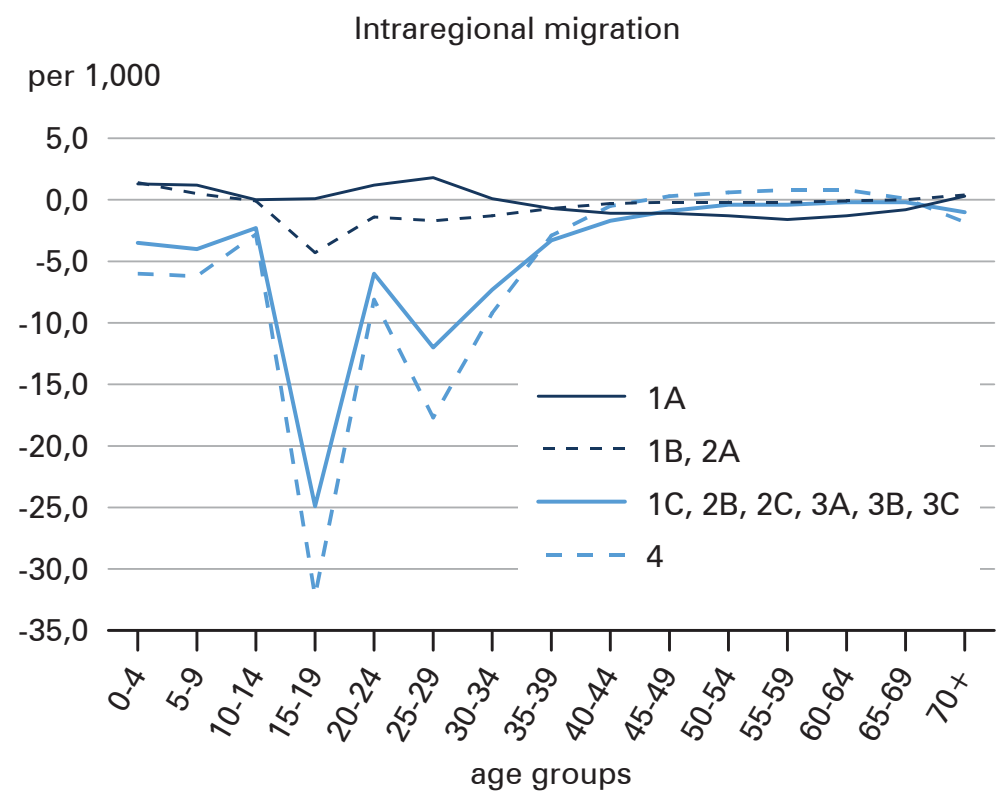

per 1,000

Interregional migration

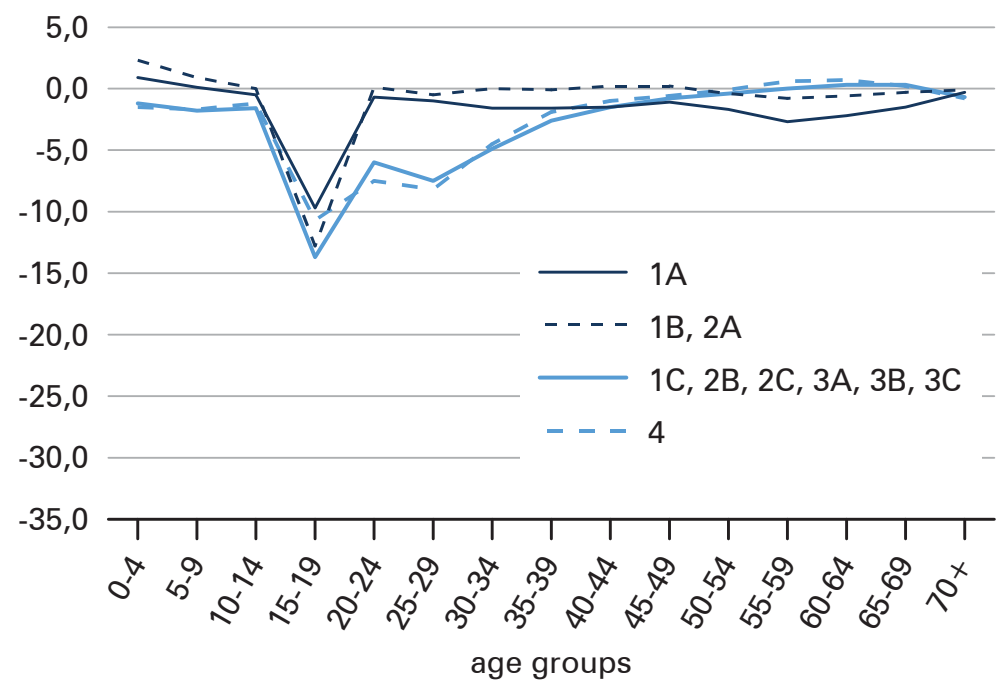

Source: Authors' computations using Russian Statistical Office, Municipal Formations Database (MFD) [https://www.gks.ru/storage/mediabank/munst.htm] 
(Bogdanova/Schukina 2013; Tkachenko 2017). Another possible reason is the access to benefits and preferential treatment that some Russian regions offer those migrants who resettle to rural areas under the State program to assist the voluntary resettlement of compatriots living abroad.

Rural areas and small peripheral cities experience the largest losses of young population due to intraregional migration (starting from the 15-19 age group). Many young people move to the regional centres to continue studies (Fig. 8). We estimate that for each student from a village or a small city going to study in the centre of another region (interregional migration), there are three migrants moving to the centre of their region for the same reason (intraregional migration). People more often choose the capital of their region for educational migration for a number of reasons. Education in the leading universities of the country is available only to a limited number of young people; additionally here is the high cost of education and the cost of living away from home (Katrovskij 1999; Gibbons/Vignoles 2012).

After graduation, the population of 20-29 year-olds in rural areas or small peripheral cities (the rank of remoteness does not matter) more often become interregional migrants than younger people aged 15-19.

Thus, the peripheral areas are not similar; MFs with large and mid-sized cities can keep young people from moving out, while small peripheral cities and rural areas experience intensive outflows of youth and insignificant inflows of elderly people.

\section{Conclusions}

Russia's population tends to concentrate in regional centres, which follows from the data on the dynamics of population size in the two latest intercensal periods. Peripheral MFs in all parts of the country suffer from a population decline; in more remote MFs, the population is decreasing faster (Karachurina/Mkrtchyan 2015). However, apart from its impact on population size, the redistribution of the population between centres and intraregional peripheral areas also results in a transformation of the age structure of the population.

In regional centres, due to migration, the share of the young working-age population is growing, which brings a positive effect in terms of economic development and creates an additional "demographic dividend".

Intraregional migration most significantly contributes to making the population of the regional centres younger. However, in line with the logic of escalator mobility (Fielding 1992) we observe the following processes: after graduation, young people move out of regional centres but not back to peripheral MFs - they migrate to the centres of other regions, primarily to Russia's largest cities, which are supra-regional centres. These cities attract migrants both from the same region and beyond. Apart from Moscow and St. Petersburg, supraregional centres include Novosibirsk, Yekaterinburg, Nizhny Novgorod, Kazan, Samara and Krasnoyarsk (Zubarevich 2013).

In regional centres, we observe the replacement of those who left with another inflow of migrants from peripheral MFs as a result of intraregional migration. The 
age structure of the population in the regional centres would not remain stable without permanent migration inflows. Many centres attract migrants of all ages, but primarily young people.

In the periphery, the outflow of young people negatively impacts the reproductive capabilities of the population and speeds up its ageing. As in other countries (Dennett/Stil/well 2010; Conway/Houtenville 2003; Raymer et al. 2007), migration inflow to peripheral MFs is composed of pre-pensioners and pensioners. However, its influence on population aging is incomparable with the impact of youth outflows from these territories. The scale of this inflow is still too insignificant and in general, pensioners in Russia rarely migrate, which is in contrast with other countries where elderly people have long been on the move.

The results of our analysis show that age-specific migration patterns in Russia are similar to those observed in other countries with regard to the mobility associated with different stages of life. On the other hand, Russia has its peculiarities. For example, as in other countries, the inflow of young people to regional centres is highest when they leave school and enrol in universities. However, in Russia, these life course events happen at the age of 18-19, while abroad, the same event can occur at an older age and last longer (Bernard et al. 2014).

We also found that in Russia, as in other developed countries (Morrill 1995; Kulu 2008; Vobecka 2010; Johnson/Winkler 2015), families with children tend to move to the suburbs of regional centres. This type of migration can be clearly observed in the Moscow suburbs, and emerges in other parts of the country (Mkrtchyan 2019). But migration from large city centres is still low, in contrast to the countries of western Europe. A wide range of factors can explain why the suburbanisation process in Russia is slow and has its own peculiarities and affects only selected territories:

1) The existence of a permanent residence registration system and the complicated process of obtaining residence registration documents during the Soviet era and in the early years after the breakup of the Soviet Union. Later, some categories of the population (e.g. pensioners) became beneficiaries of social assistance programs run by the Moscow and St. Petersburg governments, so they refrained from resettling to the suburbs so as not to lose these benefits. As long as the inflow of pre-retirement age people and elderly people to peripheral areas is negligible, it may be statistically underestimated. Many of these migrants do not change their permanent residence registration documents; therefore, they do not fall under the statistical category of migrants. Similar problems with administrative data on migrants have been identified by researchers in other eastern European countries (Gnatiuk 2017; Ouředníček 2007).

2) The middle class is slowly forming in large cities. As a result, the demand for expensive housing in suburbs remains low. Instead of moving to suburbs, many children from large cities live with their parents, with sufficient space often lacking for all family members. In the largest urban agglomerations of Russia, however, we observe a different situation. Here, the process of suburbanisation is driven by middle-class households who move from the centre of the agglomeration to its periphery and by working-age people migrating from other regions of the country. The findings of recent research (Kurichev/ Kuricheva 2018) show that both Muscovites and migrants from other regions 
account for a significant share of those who buy property in Moscow's nearest periphery.

3) During the Soviet era, housing in the suburbs was mainly for summer accommodation and had no social infrastructure (e.g. schools, hospitals, etc.). Migration to the suburbs for permanent living was substituted by temporary migration to the countryside for the summer season or for weekends (Makhrova et al. 2016).

The peculiarity of the Russian case lies in the large size and diversity of the peripheral areas. The rank of remoteness from the regional centre has no impact on the age-specific composition of migration flows in peripheral areas, but affects the intensity of the net migration decline. The age-specific migration patterns vary little across the periphery, with the key common feature being the outflow of young people. Russia inherited a centralised higher education system from the USSR; therefore, universities remain located mostly in regional centres and sometimes in other large cities. Institutions of secondary professional education are more evenly distributed across the country and can often be found in medium-sized cities or even small cities on the periphery. These educational institutions attract young migrants and help partially compensate for the outflow of the local young people to the regional centres.

The degree of the urbanisation of peripheral areas (used in this paper as a second criterion for distinguishing between different types of peripheral areas) also determines the results of migration exchange between some MFs. The inflow of young and middle-aged migrants is not observed in the peripheral areas located far from the regional centres (which makes daily commuting inconvenient) and in those peripheral areas not functioning as sub-centres (because these areas have a city with a population of $50,000-100,000$ people or more).

There are peripheral areas where the degree of urbanisation and the degree of remoteness from regional centres produce no effect on migration intensity. These are 1) territories focussing on extractive activities (chiefly oil and gas) and successfully functioning manufacturing cities that specialise in steel or machinery production, with higher income levels compared with other MFs; and 2) resort areas, primarily along the Black Sea coast. The remaining periphery can only attract pensioners if it has developed infrastructure and a mild climate, but the inflow of pensioners to this periphery is still insignificant. In our opinion, this outcome can be explained by a lack of financial resources for relocation (Guriev/Vakulenko 2015) and the difficult living conditions (in rural periphery) in the winter season.

In general, centre-periphery migration patterns in Russia correspond to those observed in the United States and Europe, especially with regard to youth migration. However, some noteworthy differences exist: 1) the outflow of population from large urban centres is still rather weak; 2) migration to the suburbs is not that widespread, and is associated with urban sprawl rather than suburbanisation; 3) migration of the elderly is a rare phenomenon, but elderly migrants, although not numerous, also choose rural areas and small cities as their destinations.

To date, the migration statistics available in Russia allow us only to partially analyse the age-migration links noted by Ravenstein $(1876,1885)$ and to argue that 
some of them are found in Russia as well. At the same time, we cannot undertake a more detailed investigation of internal migration processes. For example, unlike Ravenstein (Grigg 1977), we cannot analyse migration "step-by-step" due to the inconsistency of the data or the shortness of the time series, although such an analysis could make a relevant contribution to the studies of internal migration.

\section{Acknowledgements}

This article is an output of a research project implemented as part of the Basic Research Program at the National Research University Higher School of Economics. We would like to thank the Editors of the Special Issue for the opportunity to be among the authors of this issue and personally we would like to thank Philip Rees for his sincere and constructive questions and comments, as well as the reviewers of the article.

\section{References}

Argent, Neil; Walmsley, Jim 2008: Rural Youth Migration Trends in Australia: An Overview of Recent Trends and Two Inland Case Studies. In: Geographical Research 46,2: 139-152 [doi: 10.1111/j.1745-5871.2008.00505.x].

Bell, Martinet al. 2015: Internal Migration and Development: Comparing Migration Intensities Around the World. In: Population and Development Review 41,1: 33-58 [doi: 10.1111/j.1728-4457.2015.00025.x].

Bernard, Aude; Bell, Martin; Charles-Edwards, Elin 2014: Life-Course Transitions and the Age Profile of Internal Migration. In: Population and development review 40,2: 213-239 [doi: 10.1111/j.1728-4457.2014.00671.x].

Bernard, Aude; Bell, Martin; Charles-Edwards, Elin 2016: Internal migration age patterns and the transition to adulthood: Australia and Great Britain compared. In: Journal of Population Research 33: 123-146 [doi: 10.1007/s12546-016-9157-0].

Berry, Brian 1980: Urbanisation and Counterurbanisation in the United States. In: The Annals of the American Academy of Political and Social Science 451,1: 13-20 [doi: 10.1177/000271628045100103].

Berry, Christopher; Glaeser, Edward 2005: The divergence of human capital levels across cities. In: Papers in Regional Science 84,3: 407-444 [doi: 10.1111/j.14355957.2005.00047.x].

Bessudnov, Alexey; Kurakin, Dmitry; Malik, Valeriya 2017: The Myth about Universal Higher Education: Russia in the International Context. In: Voprosy obrazovanija (Educational Studies Moscow) 3: 83-109 [doi: 10.17323/1814-9545-2017-3-83-109].

Billari, Francesco; Liefbroer, Aaart 2010: Towards a new pattern of transition to adulthood? In: Advances in Life Course Research 15,2-3: 59-75 [doi: 10.1016/j.alcr.2010.10.003].

Blowers, Andrew; Leroy, Pieter 1994: Power, Politics and Environmental Inequality: A Theoretical and Empirical Analysis of the Process of 'Peripheralisation'. In: Environmental Politics 3,2: 197-228 [doi: 10.1080/09644019408414139]. 
Bogdanova, Lidiya; Schukina, Anna 2013: Large-scale social and demographic researches of rural areas of Tver oblast. In: Problems of Geography 135: Geography of Population and Social Geography /Editors-in-Chief A.I. Alekseev, A.A. Tkachenko. Moscow: "Kodeks" Publishing House: 397-406.

Champion, Anthony 1987: Recent changes in the pace of population deconcentration in Britain. In: Geoforum 18,4: 379-401 [doi: 10.1016/0016-7185(87)90029-7].

Champion, Tony; Hugo, Graeme, 2004: Introduction: Moving beyond the urban-rural dichotomy. In: Champion, Tony; Graeme, Hugo (Eds.): New forms of Urbanisation: Beyond the Urban-rural dichotomy. Aldershot: Ashgate Publishing: 3-24 [doi: 10.4324/9781315248073].

Champion, Tony; Coombes, Mike; Gordon, lan 2014: How far do England's second-order cities emulate London as human-capital 'escalators'? In: Population, space and place 20,5: 421-433 [doi: 10.1002/psp.1806].

Clark, William A.V.; Withers, Suzanne 2007: Family migration and mobility sequences in the United States: Spatial mobility in the context of the life course. In: Demographic Research 17,20: 591-622 [doi: 10.4054/DemRes.2007.17.20].

Conway, Karen; Houtenville, Andrew 2003: Out with the old, in with the old: A closer look at younger versus older elderly migration. In: Social Science Quarterly 84,2: 309 328 [doi: 10.1111/1540-6237.8402006].

Dasre, Aurelien et al. 2009: Age selection by migrations and sociospatial concentrations. In: Espace-Populations-Societes 1: 67-84 [doi: 10.4000/eps.3567].

de Jong, Petra; Brouwer, Aleid; McCann, Philip 2016: Moving up and down the urban hierarchy: age-articulated interregional migration flows in the Netherlands. In: Annals of Regional Science 57: 145-164 [doi: 10.1007/s00168-016-0772-7].

Dennett, Adam; Stillwell, John C.H. 2010: Internal Migration in Britain, 2000-01, Examined Through an Area Classification Framework. In: Population, Space and Place 16,6: 517-538 [doi: 10.1002/psp.554].

Détang-Dessendre, Cecile; Goffette-Nagot, Florence; Piguet, Virginie 2008: Life cycle and migration to urban and rural areas: Estimation of a mixed logit model on French data. In: Journal of Regional Science 48,4: 789-824 [doi: 10.1111/j.14679787.2008.00571.x].

Endryushko, Anna 2018: Masshtaby i napravlenija migracii molodezhi Irkutskoj oblasti (1989-2015 gg.) (Scope and Directions of youth migration of the Irkutsk region (19892015)). In: Regional'nye issledovanija (Regional research) 2: 32-43.

Fielding, Anthony 1989: Inter-regional migration and social change: a study of south east England based upon data from the longitudinal study. In: Transactions - Institute of British Geographers 14,1: 24-36 [doi: 10.2307/622340].

Fielding, Anthony 1992: Migration and Social Mobility: South East England as an Escalator Region. In: Regional Studies 26,1: 1-15 [doi: 10.1080/00343409212331346741].

Findlay, Allan et al. 2009: Escalators, elevators and travelators: The occupational mobility of migrants to South-East England. In: Journal of Ethnic and Migration Studies 35,6: 861-879 [doi: 10.1080/13691830902957676].

Fratesi, Ugo 2014: Editorial: The Mobility of High-Skilled Workers - Causes and Consequences. In: Regional Studies 48,10: 1587-1591 [doi: 10.1080/00343404.2014.955689].

Fuguitt, Glenn; Heaton, Tim 1995: The impact of migration on the nonmetropolitan population age structure, 1960-1990. In: Population Research and Policy Review 14: 215 232 [doi: 10.1007/BF01074459]. 
Geyer, Hermanus; Kontuly, Thomas 1993: A theoretical foundation of the concept of differential urbanisation. In: International Regional Science Review 15,2: 157-177 [doi: 10.1177/016001769301500202].

Gibbons, Stephen; Vignoles, Anna 2012: Geography, choice and participation in higher education in England. In: Regional Science and Urban Economics 42: 98-113 [doi: 10.1016/j.regsciurbeco.2011.07.004].

Gillies, Donald 2014: Learning and leaving: education and depopulation in an island community. In: Cambridge Journal of Education 44,1: 19-34 [doi: 10.1080/0305764X.2013.837865].

Glezer, Olga; Vainberg, Emma 2014: Prostranstvo zhiznedejatel"nosti naselenija i rasselenie kak faktory i uslovija modernizacii Rossii (The Space of Life Activities of the Population and Settlement Pattern as the Factors and Conditions of the Modernization of Russia). In: Regional Research of Russia 4,3: 136-142.

Gnatiuk, Oleksiy 2017: Demographic dimension of suburbanisation in Ukraine in the light of urban development theories. In: Acta Universitatis Carolinae, Geographica 52: 151163 [doi: 10.14712/23361980.2017.12].

Gordon, Ian; Champion, Tony; Coombes, Mike 2015: Urban escalators and interregional elevators: The difference that location, mobility, and sectoral specialisation make to occupational progression. In: Environment and Planning A 47,3: 588-606 [doi: 10.1068/ a130125p].

Grigg, David 1977: E. G. Ravenstein and the "laws of migration". In: Journal of Historical Geography 3,1: 41-54 [doi: 10.1016/0305-7488(77)90143-8].

Guriev, Sergey; Vakulenko, Elena 2015: Breaking out of poverty traps: Internal migration and interregional convergence in Russia. In: Journal of Comparative Economics 43: 633-649 [doi: 10.1016/j.jce.2015.02.002].

Haase, Annegret et al. 2017: Reurbanisation in postsocialist Europe - A comparative view of eastern Germany, Poland, and the Czech Republic. In: Comparative Population Studies 42: 353-390 [doi: 10.12765/CPoS-2018-02en].

Hansen, Hogni; Niedomysl, Thomas 2009: Migration of the creative class: evidence from Sweden. In: Journal of Economic Geography 9: 191-206 [doi: 10.1093/jeg/lbn046].

Johnson, Kenneth; Winkler, Richelle 2015: Migration signatures across the decades: Net migration by age in U.S. Counties, 1950-2010. In: Demographic Research 32,1: 10651080 [doi: 10.4054/DemRes.2015.32.38].

Kalogirou, Stamatis 2005: Examining and Presenting Trends of Internal Migration Flows within England and Wales. In: Population, Space and Place 11: 283-297 [doi: 10.1002/ psp.376].

Karachurina, Liliya; Ivanova, Kseniya 2019: Migration of the Elderly Population in Russia (According to the 2010 Population Census). In: Regional Research of Russia 9,2: 164172 [doi: 10.1134/S2079970519020059].

Karachurina, Liliya; Florinskaya, Yliya 2019: Migration intentions of school graduates in small and midsize towns of Russia. In: Vestnik Moskovskogo universiteta. Seriya 5, Geografiya (Bulletin of Moscow University. Series 5. Geography) 6: 82-89.

Karachurina, Liliya; Mkrtchyan, Nikita 2015: Population change in the regional centres and internal periphery of the regions in Russia, Ukraine and Belarus over the period of 1990-2000s. In: Bulletin of Geography 28: 91-111 [doi: 10.1515/bog-2015-0018].

Karachurina, Liliya; Mkrtchyan, Nikita 2016: The Role of Migration in Enhancing Settlement Pattern Contrasts at the Municipal Level in Russia. In: Regional Research of Russia 6,4: 332-343 [doi: 10.1134/S2079970516040080]. 
Karachurina, Liliya; Mkrtchyan, Nikita 2018: Age-specific net migration patterns in the municipal formations of Russia. In: Geo Journal 83,1: 119-136 [doi: 10.1007/s10708016-9757-4].

Kashnitsky, l/ya 2020: Russian periphery is dying in movement: a cohort assessment of internal youth migration in Central Russia. In: GeoJournal 85: 173-185 [doi: 10.1007/ s10708-018-9953-5].

Kashnitsky, Ilya; Mkrtchyan, Nikita; Leshukov, Oleg 2016: Interregional migration of youths in Russia: A comprehensive analysis of demographic statistics. In: Voprosy obrazovanija (Educational Studies Moscow) 3: 169-203 [doi: 10.17323/1814-95452016-3-169-203].

Katrovskij, Aleksandr 1999: Uchebnaja migracija v vuzy Rossii: faktory i motivacija (Educational migration in higher education institutions of Russia: factors and motivation). In: Zajonchkovskaja, Zhanna (Ed.): Migracija i urbanizacija v SNG i Baltii v 90-e gody (Migration and urbanisation in the CIS and the Baltic States in the 90th years. Moscow: 269-276.

Kauppila, Pekka 2011: Cores and peripheries in a northern periphery: A case study in Finland. In: Fennia 189,1: 20-31.

Kladivo, Petr et al. 2015: Suburbanisation and local governance - Positive and negative forms: Olomouc case study. In: Bulletin of Geography 27: 95-107 [doi: 10.1515/bog2015-0007].

Kley, Stefanie 2011: Explaining the Stages of Migration within a Life-course Framework. In: European Sociological Review 27,4: 469-486 [doi: 10.1093/esr/jcq020].

Kulu, Hill 2008: Fertility and spatial mobility in the life course: Evidence from Austria. In: Environment and Planning A 40,3: 632-652 [doi: 10.1068/a3914].

Kupiszewski, Marek; Durham, Helen; Rees, Philip 1998: Internal Migration and Urban Change in Poland. In: European Journal of Population 14: 265-290 [doi: 10.1023/A:1006058712865].

Kupiszewski, Marek et al. 2001: Internal migration and regional population dynamics in Europe: Denmark case study Working Paper 01/02. University of Leeds: Leeds.

Kurichev, Nikolai; Kuricheva, Ekaterina 2018: Relationship of Housing Construction in the Moscow Urban Agglomeration and Migration to the Metropolitan Area. In: Regional Research of Russia 8,1: 1-15 [doi: 10.1134/S2079970518010069].

Kuricheva, Ekaterina; Popov, Alexey 2015: Razvitie zhilishhnogo stroitel'stva v 2010-e gg. kak faktor transformacii Moskovskoj aglomeracii (Residencial Construction in 2010-s as a Factor of the Transformation of the Moscow Metropolitan Area). In: Regional'nye issledovanija (Regional research) 1: 104-116.

Litwak, Eugene; Longino, Charles 1987: Migration patterns among the elderly: A developmental perspective. In: The Gerontologist 27,3: 266-272 [doi: 10.1093/geront/27.3.266].

Long, Larry; Deare, Diana 1988: US Population Redistrubution: A Perspective on the Nonmetropolitan Turnaround. In: Population and Development Review 14,3: 433-450 [doi: 10.2307/1972197].

Makhrova, Alla; Kirillov, Pavel 2015: Rossijskaja urbanizacija i zhil'e gorozhan. (Urbanisation in Russia and housing of the city residents). In: Demoscope Weekly: 645-646 [http://demoscope.ru/weekly/2015/0645/tema01.php, 12.05.2019].

Makhrova, Alla; Nefedova, Tatyana; Pallot, Judith 2016: The Specifics and Spatial Structure of Circular Migration in Russia. In: Eurasian Geography and Economics 57,6: 802818 [doi: 10.1080/15387216.2016.1274663]. 
Martel, Catherine; Taylor, Andrew; Carson, Dean 2013: Changing patterns of migration to Australia's northern territory: Evidence of new forms of escalator migration to frontier regions? In: Migration Letters 10,1: 101-113 [doi: 10.33182/ml.v10i1.115].

Miller, Laura 1995: Family togetherness and the suburban ideal. In: Sociological Forum 10: 393-418 [doi: 10.1007/BF02095828].

Millington, Jim 2000: Migration and age: the effect of age on sensitivity to migration stimuli. In: Regional Studies 34,6: 521-533 [doi: 10.1080/00343400050085648].

Mkrtchyan, Nikita 2015: Migracija v Moskve i Moskovskoj oblasti: regional'nye i strukturnye osobennosti (Migration in Moscow and Moscow region: regional and structural characteristics). In: Regional'nye issledovanija (Regional research) 3: 107-116.

Mkrtchyan, Nikita 2019: Regional Capitals of Russia and Their Suburbs: Specifics of the Migration Balance. In: Regional Research of Russia 9,1: 12-22 [doi: 10.1134/ S2079970519010076].

Moiseenko, Valentina 2004: Snizhenie masshtabov vnutrennej migracii naselenija Rossii: opyt ocenki dinamiki po dannym tekushhego ucheta (Internal migration decline in Russia: assessment of migration dynamics using administrative data). In: Voprosy statistiki (Statistical Affairs) 7: 47-56.

Morrill, Richard 1995: Aging in place, age specific migration and natural decrease. In: The Annals of Regional Science 29: 41-66 [doi: 10.1007/BF01580362].

Mulder, Clara 2006: Population and housing: A two-sided relationship. In: Demographic Research 15,13: 401-412 [doi: 10.4054/DemRes.2006.15.13].

Nefedova, Tatyana; Treivish, Andrei 2003: Differential urbanisation in Russia. In: Tijdschrift voor Economische en Sociale Geografie 94,1: 75-88 [doi: 10.1111/14679663.00238].

Nefedova, Tatyana; Treivish, Andrei 2017: The transformation of settlement in modern Russia: urbanisation or de-urbanisation? In: Regional'nye issledovanija (Regional research) 2: 12-23.

Neretin, Aleksandr 2018: Transportnoe polozhenie i dostupnost' territorij Evropejskoj Rossii (Transport situation and accessibility of the territories of European Russia). PhD Thesis. Moscow: Institute of Geography, Russian Academy of Sciences.

Neretin, Aleksandr; Zotova, Mariya; Lomakina, Anastasiya; Tarkhov, Sergey 2019: Transport Connection and Development of the Eastern Regions of Russia. In: Izvestiya Rossiiskoi Akademii Nauk. Seriya Geograficheskaya (Proceedings of the Russian Academy of Sciences. Geographical Series) 6: 35-52 [doi: 10.31857/S2587-55662019635-52].

Ouředníček, Martin 2007: Differential suburban development in the Prague urban region. In: Geografiska Annaler: Series B, Human Geography 89,2: 111-126 [doi: 10.1111/j.14680467.2007.00243.x].

Pileček, Jan; Chromy, Pavel; Jančak, Vit 2013: Social Capital and Local Socio-economic Development: The Case of Czech Peripheries. In: Tijdschrift voor Economische en Sociale Geografie 104,5: 604-620 [doi: 10.1111/tesg.12053].

Philip, Lorna; Macleod, Marsaili; Stockdale, Aileen 2013: Retirement Transition, Migration and Remote Rural Communities: Evidence from the Isle of Bute. In: Scottish Geographical Journal 129,2: 122-136 [doi: 10.1080/14702541.2013.783616].

Plane, David; Heins, Frank 2003: Age articulation of U.S. inter-metropolitan migration flows. In: Annals of Regional Science 37: 107-130 [doi: 10.1007/s001680200114].

Plane, David; Henrie, Christopher; Perry, Marc 2005: Migration up and down the urban hierarchy and across the life course. In: Proceedings of the National Academy of Sciences 102: 15313-15318 [doi: 10.1073/pnas.0507312102]. 
Plane, David; Jurjevich, Jason 2009: Ties That No Longer Bind? The Patterns and Repercussions of Age Articulated Migration. In: The Professional Geographer 61,1: 4-20 [doi: 10.1080/00330120802577558].

Polèse, Mario; Shearmur, Richard 2006: Why some regions will decline: A Canadian case study with thoughts on local development strategies. In: Papers in Regional Science 85,1: 23-46 [doi: 10.1111/j.1435- 5957.2006.00024.x].

Raagmaa, Garry 2003: Centre-Periphery model explaining the regional development of the informational and transitional society. In: 43rd Congress of the European regional science association (ERSA) Jyvaskyla, Finland, August 27-30 [https://www.jyu.fi/ ersa2003/cdrom/papers/503.pdf, 18.05.2020].

Rahmanova, Galina 1994: Vozrastnye profili migracii v Rossii i ee regionah: 80 -e i nachalo $90-\mathrm{h}$ gg. (The age profiles of migration in Russia and its regions: the 80th and the beginning of the $\left.90^{\text {th }}\right)$. In: Zajonchkovskaja, Zhanna (Ed.): Migracionnye processy posle raspada SSSR (Migratory processes after the collapse of the USSR. V). Moscow: 82-113.

Raymer, James; Abel, Guy; Smith, Peter 2007: Combining census and registration data to estimate detailed elderly migration flows in England and Wales. In: Royal Statistical Society 170,4: 891-908 [doi: 10.1111/j.1467-985X.2007.00490.x].

Ravenstein, Ernst 1876: The Birthplaces of the People and the Laws of Migration. In: The Geographical Magazine 3: 173-177, 201-206, 229-233.

Ravenstein, Ernst 1885: The Laws of Migration. In: Journal of the Statistical Society of London 48,2: 167-235 [doi: 10.2307/2979181].

Ravenstein, Ernst 1889: The laws of migration: Second Paper. In: Journal of the Royal Statistical Society 52,2: 241-305 [doi: 10.2307/2979333].

Rees, Philip; Durham, Helen; Kupiszewski, Marek 1996: Internal Migration and Regional Population Dynamics in Europe: United Kingdom Case. Working Paper 96/20.

Rees, Philip; Kupiszewski, Marek 1999: Internal Migration and Regional Population Dynamics in Europe: A Synthesis. Strasbourg: Council of Europe Publishing.

Rees, Philip et al. 2017: The Impact of Internal Migration on Population Redistribution: an International Comparison. In: Population, Space and Place 23,6: e2036 [doi: 10.1002/ psp.2036].

Rerat, Patrick et al. 2008: Age structure of Swiss cities: Residential mobility, life course and attractiveness. In: Geographica Helvetica 63,4: 261-271 [doi: 10.5194/gh-63-2612008].

Rogerson, Peter; Burr, Jeffrey; Ge, Lin 1997: Changes in geographic proximity between parents and their adult children. In: International Journal of Population Geography 3,2: 121-136 [doi: 10.1002/(SICI)1099-1220(199706)3:2<121::AID-IJPG60>3.0.CO;2-I].

Rosstat 2013: The population of the Russian Federation by municipal formations as of January 1, 2012. Statistical Bulletin. Moscow.

Sander, Nikola, 2014: Internal migration in Germany, 1995-2010: New insights into EastWest migration and re-urbanisation. In: Comparative Population Studies 39,2: 217-246 [doi: 10.12765/CPoS-2014-04en].

Savage, Mike; Fielding, Tony 1989: Class formation and regional development: the 'service class' in South East England. In: Geoforum 20,2: 203-218. [doi: 10.1016/00167185(89)90040-7].

Smetkowski, Maciej 2011: Socio-spatial differentiation in Warsaw: Inertia or metamorphosis of the city structure? In: Geographia Polonica 84,2: 115-133 [doi: 10.7163/ GPol.2011.2.8]. 
Stillwell, John; Boden, Peter; Rees, Philip 1990: Trends in internal net migration in the UK: 1975 to 1986. In: Area 22,1: 57-65.

Stockdale, Aileen 2014: Unravelling the migration decision-making process: English early retirees moving to rural mid-Wales. In: Journal of Rural Studies 34: 161-171 [doi: 10.1016/j.jrurstud.2014.01.010].

Tihonov, Boris 1978: Pereselenija v Rossii vo vtoroj polovine XIX veka. Po materialam perepisi 1897 goda i pasportnoj statistiki (Resettlement in Russia in the second half of the twentieth century. Based on materials from the 1897 census and passport statistics). Moskow: Nauka.

Tkachenko, Alexandr 2017: O kolichestve sel'skih naselennyh punktov v Tverskoj oblasti (Discussing the number of rural settlements in the Tver region). In: Vestnik Tverskogo Gosudarstvennogo Universiteta. Serija: Geografija i geojekologija (Bulletin of Tver State University. Series Geography and Geoecology) 3: 6-16.

Winters, John 2011: Why are smart cities growing? Who moves and who stays. In: Journal of Regional Science 51,2: 253-270 [doi: 10.1111/j.1467-9787.2010.00693.x].

Vining, Daniel; Pallone, Robert 1982. Migration between Core and Peripheral Regions: a Description and Tentative Explanation of the Patterns in 22 Countries. In: Geoforum 13,4: 339-410 [doi: 10.1016/0016-7185(82)90031-8].

Vishnevskij, Anatoliy (Ed.) 2014: Naselenie Rossii 2012: dvadcatyj ezhegodnyj demograficheskij doklad (The population of Russia 2012: Twentieth annual demographic report). Moscow: Izdatelskij dom Vysshej shkoly jekonomiki.

Vobecka, Jana 2010: Spatial dynamics of the population in the Czech Republic, 19892007. Ph.D. Thesis. Charles University in Prague; Universite de Bourgogne in Digon.

Zajonchkovskaya, Zhanna; Mkrtchyan, Nikita 2009: Rol' migracii v dinamike chislennosti i sostava naselenija Moskvy (The role of migration in the dynamics of the number and composition of the population of Moscow). In: Zajonchkovskaya, Zhanna (Ed.): Immigranty v Moskve (Immigrants in Moscow). Moscow: 18-44.

Zamjatina, Nadezhda; Jashunskij, Aleksej 2012: Mezhregional'nye centry obrazovanija (Interregional Education Centres). In: Otechestvennye zapiski (Domestic notes) 5: 227 239.

Zubarevich, Natalia 2010: Goroda kak centry modernizacii jekonomiki i chelovecheskogo kapitala (Cities have centres for the modernization of the economy and human capital). In: Obshhestvennye nauki i sovremennost' (Social sciences) 5: 5-19.

Zubarevich, Natalia 2013: Krupnye goroda Rossii: lidery i autsajdery (Major Cities: Leaders and Outsiders). In: Demoskope Weekly 551-552 [http://www.demoscope.ru/weekly/2013/0551/demoscope551.pdf, 18.05.2020].

Prof. Dr. Liliya Karachurina ( $\varangle)$, Prof. Dr. Nikita Mkrtchyan. National Research University Higher School of Economics, Department of Demography. Moscow, Russia.

E-mail: Ikarachurina@hse.ru,nmkrtchyan@hse.ru

URL: https://www.hse.ru/en/org/persons/65552

https://www.hse.ru/en/org/persons/203471 


\section{Appendix 1}

\section{Administrative-territorial units (regions) in Russia}

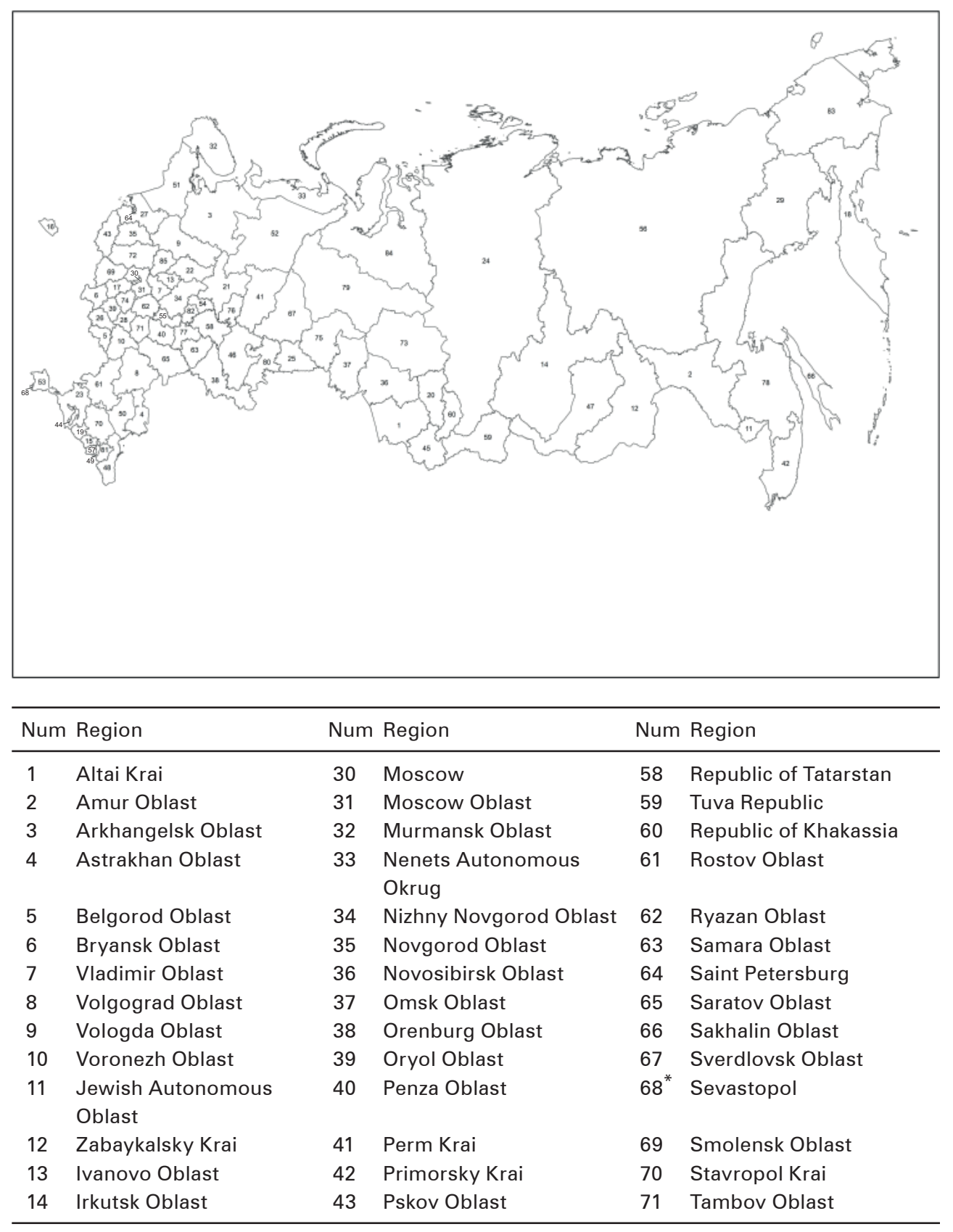




\section{Continuation}

\begin{tabular}{|c|c|c|c|c|c|}
\hline Num & Region & Num & Region & Num & Region \\
\hline 15 & $\begin{array}{l}\text { Kabardino-Balkar } \\
\text { Republic }\end{array}$ & 44 & Republic of Adygea & 72 & Tver Oblast \\
\hline 16 & Kaliningrad Oblast & 45 & Altai Republic & 73 & Tomsk Oblast \\
\hline 17 & Kaluga Oblast & 46 & $\begin{array}{l}\text { Republic of } \\
\text { Bashkortostan }\end{array}$ & 74 & Tula Oblast \\
\hline 18 & Kamchatka Krai & 47 & Republic of Buryatia & 75 & Tyumen Oblast \\
\hline 19 & $\begin{array}{l}\text { Karachay-Cherkess } \\
\text { Republic }\end{array}$ & 48 & Republic of Dagestan & 76 & Udmurt Republic \\
\hline 20 & Kemerovo Oblast & 49 & Republic of Ingushetia & 77 & Ulyanovsk Oblast \\
\hline 21 & Kirov Oblast & 50 & Republic of Kalmykia & 78 & Khabarovsk Krai \\
\hline 22 & Kostroma Oblast & 51 & Republic of Karelia & 79 & $\begin{array}{l}\text { Khanty-Mansi } \\
\text { Autonomous Okrug - } \\
\text { Yugra }\end{array}$ \\
\hline 23 & Krasnodar Krai & 52 & Komi Republic & 80 & Chelyabinsk Oblast \\
\hline 24 & Krasnoyarsk Krai & $53^{*}$ & Republic of Crimea & 81 & Chechen Republic \\
\hline 25 & Kurgan Oblast & 54 & Mari El Republic & 82 & Chuvash Republic \\
\hline 26 & Kursk Oblast & 55 & Republic of Mordovia & 83 & $\begin{array}{l}\text { Chukotka Autonomous } \\
\text { Okrug }\end{array}$ \\
\hline 27 & Leningrad Oblast & 56 & $\begin{array}{l}\text { Republic of Sakha } \\
\text { (Yakutia) }\end{array}$ & 84 & $\begin{array}{l}\text { Yamalo-Nenets } \\
\text { Autonomous Okrug }\end{array}$ \\
\hline 28 & Lipetsk Oblast & 57 & $\begin{array}{l}\text { Republic of North } \\
\text { Ossetia - Alania }\end{array}$ & 85 & Yaroslavl Oblast \\
\hline 29 & Magadan Oblast & & & & \\
\hline
\end{tabular}

* Note: As of 1 January 2012 there were 83 regions in Russia

Source: Compiled by authors using "Rosstat 2013: The population of the Russian Federation by municipal formations as of January 1, 2012. Statistical Bulletin. Moscow" 


\section{Comparative Population Studies}

WWW.comparativepopulationstudies.de

ISSN: 1869-8980 (Print) - 1869-8999 (Internet)

\section{Published by}

Prof. Dr. Norbert F. Schneider

Federal Institute for Population Research D-65180 Wiesbaden / Germany

\section{(c) BY-SA}

2019

\section{Managing Editor \\ Prof. Philip Rees \\ Dr. Katrin Schiefer}

\section{Copy Editor}

Julia Luther

\section{Editorial Assistant}

Beatriz Feiler-Fuchs

Wiebke Hamann

\section{Layout \\ Beatriz Feiler-Fuchs \\ E-mail:cpos@bib.bund.de}

\section{Scientific Advisory Board}

Karsten Hank (Cologne)

Michaela Kreyenfeld (Berlin)

Marc Luy (Vienna)

Natalie Nitsche (Vienna)

Peter Preisendörfer (Mainz)

Zsolt Spéder (Budapest)

Rainer Wehrhahn (Kiel)

\section{Board of Reviewers}

Martin Abraham (Erlangen)

Laura Bernardi (Lausanne)

Hansjörg Bucher (Bonn)

Claudia Diehl (Konstanz)

Andreas Diekmann (Zurich)

Gabriele Doblhammer-Reiter (Rostock)

Jürgen Dorbritz (Wiesbaden)

Anette Eva Fasang (Berlin)

E.-Jürgen Flöthmann (Bielefeld)

Alexia Fürnkranz-Prskawetz (Vienna)

Beat Fux (Salzburg)

Joshua Goldstein (Berkeley)

Sonja Haug (Regensburg)

Hill Kulu (Liverpool)

Aart C. Liefbroer (The Hague)

Kurt Lüscher (Konstanz)

Emma Lundholm (Umeå)

Nadja Milewski (Rostock)

Dimiter Philipov (Vienna)

Roland Rau (Rostock)

Tomáš Sobotka (Vienna)

Jeroen Spijker (Barcelona)

Olivier Thévenon (Paris)

Helga de Valk (Brussels)

Heike Trappe (Rostock)

Michael Wagner (Cologne) 